Review

\title{
Current targets and drug candidates for prevention and treatment of SARS-CoV-2 (COVID-19) infection
}

\author{
Ramesh K. Goyal ${ }^{1, *}$, Jaseela Majeed ${ }^{1}$, Rajiv Tonk ${ }^{1}$, Mahaveer Dhobi ${ }^{1}$, Bhoomika Patel ${ }^{2}$, Kalicharan Sharma ${ }^{3}$ and \\ Subbu Apparsundaram ${ }^{1}$
}

\author{
${ }^{1}$ Delhi Pharmaceutical Sciences and Research University, New Delhi - 110017, Delhi, India \\ ${ }^{2}$ Institute of Pharmacy, Nirma University, Ahmedabad - 382481, Gujarat, India \\ ${ }^{3}$ Mankind Research Center, Gurgaon-122050, Haryana, India \\ *Correspondence: goyalrk@gmail.com (Ramesh K. Goyal)
}

DOI: $10.31083 /$ i.rcm.2020.03.118

This is an open access article under the CC BY 4.0 license (https://creativecommons.org/licenses/by/4.0/).

Angiotensin-converting enzyme 2 (ACE2), the host cellbinding site for SAR-CoV-2, poses two-fold drug development problems. First, the role of ACE2 itself is still a matter of investigation, and no specific drugs are available targeting ACE2. Second, as a consequence of SARS-CoV2 interaction with ACE2, there is an impairment of the renin-angiotensin system (RAS) involved in the functioning of vital organs like the heart, kidney, brain, and lungs. In developing antiviral drugs for COVID-19, ACE2, RNAdependent RNA polymerase (RdRp), and the specific enzymes involved in the viral and cellular gene expression have been the primary targets. SARS-CoV-2 being a new virus with unusually high mortality, there has been a need to get medicines in an emergency, and the drug repurposing has been a primary strategy. Considering extensive mortality and morbidity throughout the world, we have made a maiden attempt to discover the drugs interacting with RAS and identify the lead compounds from herbal plants using molecular docking. Both host ACE2 and viral RNA-dependent RNA polymerase (RdRp) and ORF8 appear to be the primary targets for the treatment of COVID19. While the drug repurposing of currently approved drugs seems to be one strategy for the treatment of COVID19, purposing phytochemicals may be another essential strategy for discovering lead compounds. Using in silico molecular docking, we have identified a few phytochemicals that may provide insights into designing herbal and synthetic therapeutics to treat COVID-19.

\section{Keywords}

COVID-19; ACE2; SARS-CoV-2; antiviral; phytoconstituents; molecular docking

\section{Introduction}

With the declaration of Severe Acute Respiratory Syndrome Coronavirus-2 (SARS-CoV-2) as the pandemic by WHO, it has emerged as a public health emergency worldwide. The dreaded face of the SARS-CoV-2, commonly known now as Coronavirus disease-19 (COVID-19), can be realized by the fact that there is a consistent increase in the number of cases reaching above 32 mil- lion cases and above 1 million deaths worldwide (World Health Organization., 2020). Although the fight against any disease has been an endless task for humanity, the emergence of COVID-19 disease with characteristics of the top five causes of mortality in the world has posed the most significant challenges for drug discovery for the treatment of this disease. There is current guidance for early ambulatory treatment of COVID-19 based on pathophysiologic principles regarding viral replication, immune dysregulation, and thrombosis. This algorithm is designed to welcome new drug candidates for testing in clinical trials and when demonstrated to be effective, incorporation into clinical practice (McCullough et al., 2020).

COVID-19 being the novel virus, the first challenge is to develop an antiviral drug that can effectively stop its replication after entry into the human body. The targets in the development of antiviral drugs include the receptor protein to which the virus binds, the enzymes or nucleosides that facilitate the replication of viral RNA or DNA, and the proteins involved in uncoating, shedding of viruses or release of its contents (Paintsil and Cheng, 2009). It is a well-known fact that the development of the auto-resistance (immunity) is the ultimate answer for the cure of the viral disease once the virus enters the human system. The development of specific interferons is a strategy for developing new antiviral drugs (Samuel, 2001). Although SARS-CoV-2 nonstructural proteins nsp13, nsp14, nsp15, and orf6 may inhibit interferon signaling (Y. Yuen et al., 2020), IFN $\beta$-1a significantly increased discharge rate on day 14 and decreased 28-day mortality (Davoudi-Monfared et al., 2020). Thus, enhancing immunity against SARS-CoV-2 needs further investigation.

SARS-CoV-2 binds to Angiotensin-Converting Enzyme 2 (ACE2), a site that is also involved in the pathology of leading causes of mortality in the world, including cardiovascular, respiratory, and GI dysfunction. ACE2 is a mystery to the medical scientists as it regulates the renin-angiotensin system (RAS), which in turn, has an influence on the cardiovascular system, including the vital organs, kidney, heart, brain, lungs, and vasculature (Patel et al., 2016). Further, it is still unclear whether ACE2 alone or in concert with angiotensin receptors AT1, AT2, or Mas receptors contribute to the pathology of COVID-19. 
Third and yet another critical challenge is to control the harmful effects induced by the interference of ACE2. The immediate problem when a virus enters the human body is to control the patient's intermittent pathological damage. The antiviral drug could prevent morbidity and mortality if given before the virus has produced sufficient copies or has not infected an adequate number of cells in the body. It is also efficacious if the virus's time to produce morbidity and mortality is long enough. The present review article focuses on these challenges identifying new drug targets and strategies for developing treatments for ACE2-induced derangement of RAS responsible for morbidity and mortality (Danser et al., 2020; Messerli et al., 2020).

\section{Significance of RAS in the development of drugs for COVID-19}

It is now well established that membrane-anchored ACE2 is the site of cell entry for COVID-19. Epithelial cells of the lung, intestine, kidney, heart, and blood vessels express ACE2. ACE2 is also present in the oral and nasal mucosa, skin, lymph nodes, thymus, bone marrow, spleen, liver, and brain (Bilinska et al., 2020; Chen et al., 2020; Hamming et al., 2004; Li et al., 2020a; Zhang et al., 2020), regulating the vasculature, inflammation, oxidative stress, fibrosis, and cell proliferation. Indeed, COVID-19 is associated with both pulmonary pathology and extrapulmonary manifestations in multiple vital systems, including hematologicimmune, cardiovascular, renal, gastrointestinal and hepatobiliary, endocrine-neurologic, and ophthalmic dysfunctions (Gupta et al., 2020; Wiersinga et al., 2020). Furthermore, the interindividual clinical variability associated with COVID-19 vulnerability and severity, are influenced by differences in the expression of ACE2 (Babadaei et al., 2020; Benetti et al., 2020).

ACE2 regulates Ang II action by hydrolyzing Ang II to Ang17 (Pai et al., 2017; Verdecchia et al., 2020). Ang1-7 exerts antiinflammatory, antithrombotic, antihypertensive, antiarrhythmic, and cardioprotective action through G-protein-coupled Mas receptors (MasR) (Bourgonje et al., 2020; Kuba et al., 2013; Santos et al., 2018; Uhal et al., 2011). Ang II is produced by ACE, a zinc metalloproteinase that converts the hormone Ang I to Ang II. Ang II acting via AT1 receptors causes vasoconstriction, inflammation, cytokine secretion, thrombosis, endothelial and myocardial dysfunction. Ang II also acts on AT2 receptors to reduce inflammation and oxidative stress (Mehta and Griendling, 2007). Thus, ACE and ACE2 arms of RAS counterbalance their actions fine-tuning many physiological functions (Fig. 1).

ACE2 has an extracellular receptor site for the binding of viral spike (S) proteins leading to the virus's entry into the host cell, especially into lung alveolar epithelial cells and intestinal enterocytes due to high expression of ACE2 in these epithelial cells. Binding of SARS-CoV-2 to ACE2 triggers the internalization of ACE2-virus complex and consequent reduction in ACE2 levels. This leads to an imbalance between ACE2 and ACE arms of RAS. Reduced Ang17 action and increased AT1 activation trigger a cascade of inflammatory responses (Tay et al., 2020). Administration of exogenous Ang1-7 and recombinant circulating ACE2 that could serve as a decoy for SARS-CoV-2 binding to membrane ACE2 are under investigation for COVID-19 treatment. Furthermore, angiotensin receptor blockers (ARBs) and ACE inhibitors are also under investigation in the treatment of COVID-19 (Birnbaum, 2020; Inal, 2020;
Lopes et al., 2020).

It is very well documented that imbalance in the levels of ACE, and ACE2 function during COVID-19 infection is one of the factors augmenting the cytokine storm (Crowley and Rudemiller, 2017; Gheblawi et al., 2020). There is a crosstalk between RAS and complement system since Ang II and AT1 receptor activation activates complement cascade viz. C5a and C5b-9 (Java et al., 2020; Van Laecke and Van Biesen, 2017). Ang II causes phosphorylation of the p65 subunit of NF- $\kappa \mathrm{B}$, thereby causing activation of the NF- $\kappa \mathrm{B}$ pathway (Jamaluddin et al., 2000; Ruiz-Ortega et al., 2001; Skurk et al., 2004). Activation of AT1 and AT2 results in the enhanced generation of various cytokines like IL-1 $\beta$, TNF $\alpha$, IL-10, and IL-6 (Sano et al., 2000).

Moreover, activating the AT1 receptor, Ang II causes regulation of the Mitogen-Activated Protein Kinases pathway, which ultimately regulates the release of $\mathrm{TNF} \alpha$ and various interleukins (Arthur and Ley, 2013). Reduced ACE2 function amplifies cytokine storm due to coronavirus, ultimately causing multiorgan damage, thrombosis, and vital organ failure. Dysfunction of gastrointestinal RAS results in changes in microbiota and absorption of vital nutrients (Viana et al., 2020). Viral structural and nonstructural proteins may bind to the porphyrin in hemoglobin, producing a high methemoglobin-like pathology resulting in reduced oxygen-carrying capacity in the blood (Liu and Li, 2020). Such patients eventually develop pneumonia which leads to substantial gas exchange obstruction, causing hypoxemia, diminishing the energy supplied by cell metabolism, and an upsurge in anaerobic fermentation, destruction of phospholipid layer of the cell membrane by intracellular acidosis, generation of oxygen free radicals, finally causing respiratory distress. The development of acute respiratory distress syndrome and episodes of thromboembolism that may lead to disseminated intravascular coagulation due to multiple derangements of the coagulation system represent the primary causes of lethality during SARS CoV 2 infection. Recently, Tang et al. (2020) retrospectively analyzed conventional coagulation results and outcomes of 183 consecutive patients with confirmed COVID-19 infection. It was reported that that during the course of the infection of COVID-19 patients had higher levels of D-dimer and fibrin degradation products along with longer prothrombin and activated partial thromboplastin times as compared to survivors. This was confirmed by some other studies (Zou et al., 2020). The thromboembolic events appear to be due to the development of disseminated intravascular coagulation provoked by SARS-CoV2 infection and may represent a secondary anti-phospholipid antibody syndrome. Hence, anticoagulants and corticosteroids being accepted as important therapeutic regime to improve the clinical course of patients. In addition, specific anti-B cell antibodies rituximab and ocrelizumab, the anti-C5a mAb eculizumab, small molecule inhibitors of Toll-like receptor 4 signaling such as resatorvid or GLS-1027 R may be considered as futuristic therapeutics for the management of COVID-19-related thrombosis. (Cavalli et al., 2020).

Siddiqi and Mehra (2020) proposed three stage-sequence of SARS-CoV-2 infection (Siddiqi and Mehra, 2020). These three stages are also referred to as mild-to-moderate no risk, mild-tomoderate risk, and severe disease groups (Dehelean et al., 2020). During the Stage-I (mild-to-moderate no risk) infection involving innate immunity, treatment with convalescent sera, and non- 


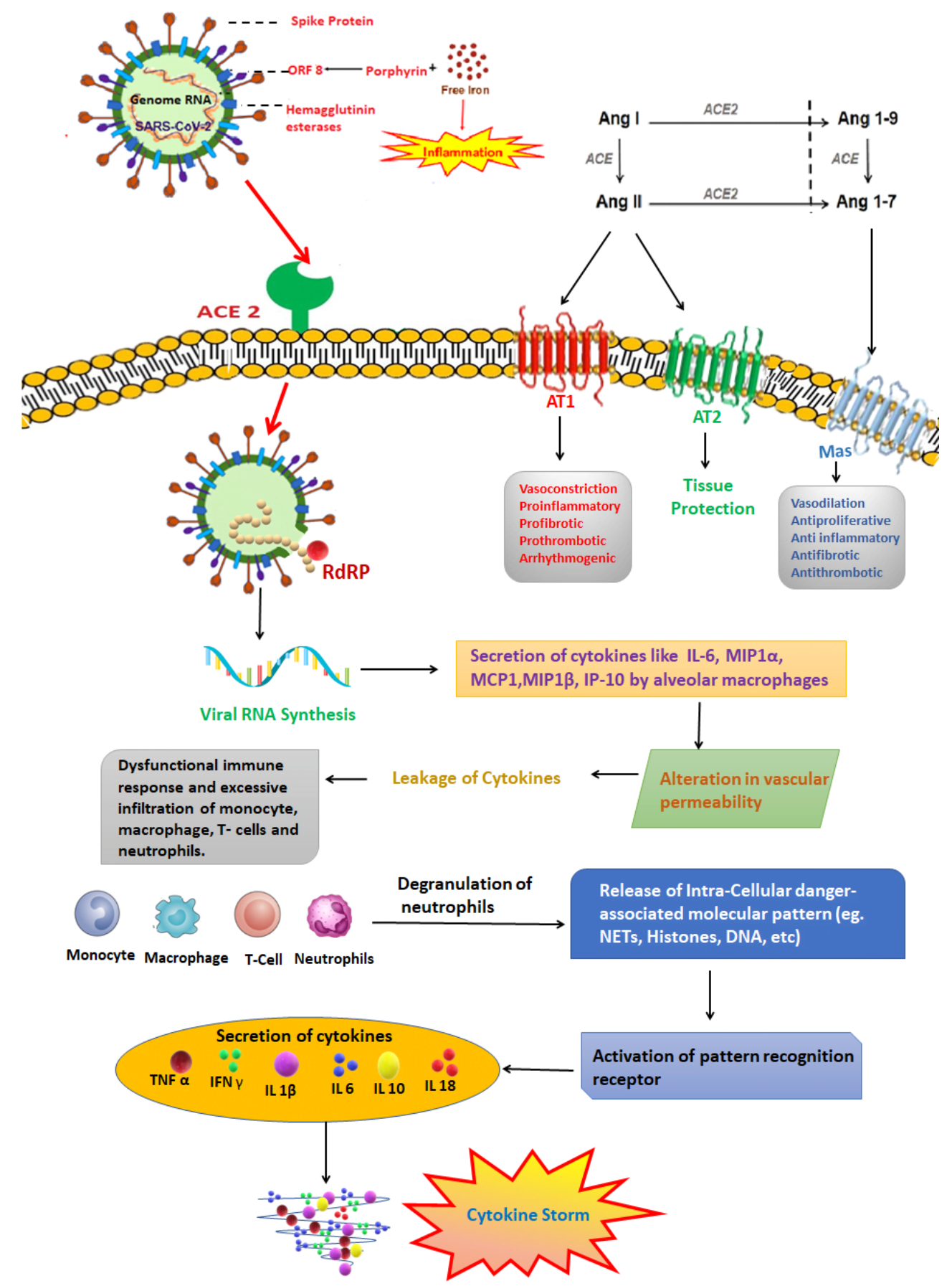

Fig. 1. Overview of SARS-CoV-2 infection and renin-angiotensin system: During the COVID-19 infection, the SARS-CoV-2 binds to the angiotensin-converting enzyme 2 (ACE2) receptors present on the cell surface which undergo endocytosis, and the virus enters inside the cell. Upon entering the cell, it synthesizes RNA using the host metabolic processes in which enzyme RNA dependent RNA polymerase (RdRp) is essential. Due to cellular damage caused by the virus, the alveolar macrophages generate various proinflammatory cytokines like interleukin-6 (IL-6), macrophage inflammatory protein $1 \alpha(\mathrm{MIP} 1 \alpha)$, monocyte chemoattractant protein 1 (MCP1), MIP1 $\beta$, interferon $\gamma$-induced protein-10 (IP-10) resulting in alterations in the vascular permeability. There is leakage of cytokines, promoting more inflammation with dysfunctional immune responses and infiltration of inflammatory cells like monocytes, macrophages, and T-cells, ultimately producing cytokine storm. There is an infiltration of neutrophils that undergoes degranulation leading to the generation of neutrophil extracellular traps (NETs). The circulating ACE2 converts angiotensin (Ang) I to angiotensin1-9 and angiotensin II to angiotensin1-7. The ACE converts angiotensin I to angiotensin II and angiotensin1-9 to angiotensin1-7. Angiotensin II binds to angiotensin 1 (AT1) receptors to produce vasoconstriction, proinflammatory, profibrotic, prothrombotic, and arrhythmogenic action. Angiotensin II also acts on AT2 receptors to mediate tissue protection. Angiotensin 1-7 binds to the MAS receptor to produce vasodilatory, antiproliferative, anti-inflammatosry, antifibrotic, and antithrombotic actions. 
specific (polyvalent) immunoglobulins may be effective. During Stage-II, there is virus replication, which leads to severe lung inflammation (viral pneumonia) resulting from the release of proinflammatory mediators and consequent multiple organ failure. Moreover, massive release of proinflammatory cytokines is also responsible for neuropsychiatric symptoms associated with COVID19 that are mediated by proinflammatory cytokines such as depression (Ettman et al., 2020; Petralia et al., 2020).

Antiviral therapy and anti-inflammatory therapy, such as antiIL-6, may be combined. In Stage-III, there is a marked hyperinflammation. In the RECOVERY trial, low dose dexamethasone reduces deaths in patients hospitalized with COVID-19 who need ventilation. Dexamethasone also reduced mortality by $20 \%$ in other hospitalized patients receiving oxygen only. However, there was no benefit among patients who did not require respiratory support. In patients hospitalized with COVID-19, the use of a low dose of dexamethasone resulted in lower 28-day mortality among those receiving either invasive mechanical ventilation or oxygen alone, but not among those receiving no respiratory support (Horby et al., 2020; Mahase, 2020). Dexamethasone benefits for patients with COVID19 likely arise from its immunosuppressive properties. Moreover, the use of low-dose dexamethasone may reduce the development of glucocorticoid resistance.

Glutathione depletion, as observed in Glucose 6-phosphate dehydrogenase (G6PD) deficient subjects, predisposes them to hemolysis upon SARS-CoV-2 infection. When administered to G6PD-deficient patients with severe COVID-10 disease, Nacetylcysteine (NAC) reverses glutathione depletion, suppressed hemolysis, and elevated liver enzymes, C-reactive protein (CRP), and ferritin, leading to full recovery of the G6PD-deficient patient. NAC also produced clinical improvement in 9/10 respiratordependent COVID-19-infected patients without G6PD deficiency, possibly by suppressing the cytokine storm (Ibrahim et al., 2020b). In the last two decades, there has been an outburst of two major similar coronavirus severe respiratory pandemics in humans, i.e., Severe Acute Respiratory Syndrome (SARS) in 2003, Middle East Respiratory Syndrome (MERS) in 2012. SARS and MERS are caused by SARS-CoV and MERS-CoV viruses enters into host cells via their interaction with ACE2 and DPP4, respectively (Gorbalenya et al., 2020; Hilgenfeld and Peiris, 2013; Zhong et al., 2003). Various studies also depict the relationship between cardiovascular, metabolic diseases, and SARS and MERS infections (Badawi and Ryoo, 2016; Yang et al., 2006). However, there are no therapeutically proven inhibitors of ACE2 for the treatment of coronavirus infections. In the absence of authenticated medicine available, clinical management of the patient in the ICU is a great challenge.

Various parts of the world have revealed that cardiovascular disturbances, including hypertension and thrombotic events, diabetes, and acute respiratory distress, are emerging comorbidities. Patients with existing cardiovascular diseases face a higher risk of COVID19 (Kuno et al., 2020; Li et al., 2020b; Richardson et al., 2020b). In patients with cardiovascular diseases, diabetes mellitus, and hypertension treated with ACE inhibitors and ARBs, the expression of ACE2 contributes to worsening the prognosis of COVID-19 patients (Birnbaum, 2020; Cannata et al., 2020; Fosbøl et al., 2020; Mackey et al., 2020; Pirola and Sookoian, 2020; Silhol et al., 2020). In contrast, several recent clinical studies provide evidence that
ACE inhibitors and ARBs may be beneficial in COVID-19 patients with hypertension and, hence, recommend continuing ACE inhibitors and ARBs (Kang et al., 2020; Mackey et al., 2020).

During the management of the patients, it is necessary to consider RAS's role holistically when SARS-CoV-2 occupies the ACE2 receptors. The conventional de novo drug discovery process takes 10 to 15 years for a drug to become available for human use, and the chance of success rate is less than 10\% (Gilbert et al., 2003; Reichert, 2003). The drug repurposing/repositioning has emerged as a fast and safe drug discovery strategy to develop effective medication, especially in case of diseases where no viable treatment is available (Ashburn and Thor, 2004; Beck et al., 2020). While attempts are ongoing to target ACE2 for developing new antivirals, the repurposing strategies to consider the use of ACE inhibitors and ARBs are also evolving.

Various drugs evaluated against SARS-CoV and MERS-CoV have been explored in terms of efficacy for repurposing during the SARS-CoV-2 outbreak (Horie et al., 2020; Kandimalla et al., 2020; Kalra et al., 2020; Pizzorno et al., 2020; Santos et al., 2020). Synthetic drugs (example chloroquine and hydroxychloroquine), and antivirals (remdesivir and favipiravir) and herbal phytoconstituents (baicalin, glycyrrhizin, hesperetin, quercetin, and scutellarin), are considered for COVID-19 due to their potential action on host ACE2 or RdRp (Chen et al., 2004; Ekins et al., 2020; Ho et al., 2007; Zhang and Yap, 2004). None of the other antiviral therapeutic interventions like Lopinavir/Ritonavir, and Remdesivir seemed to alter the natural clinical course of the disease based on the available literature (Romagnoli et al., 2020; Rosendaal, 2020), however multiple investigations are ongoing.

Besides the repurposing efforts, in silico molecular docking and simulations studies revealed potential synthetic and naturally occurring compounds in herbal and medicinal plants that interact with both viral and host target proteins (Amin and Abbas, 2020; Gao et al., a; Maurya et al., 2020; da Silva et al., 2020). These compounds targeted the SARS-CoV-2 spike proteins (Abdelli et al., 2020; Kiran et al., 2020; Maurya et al., 2020; Zhang et al., 2005) Mpro (Ibrahim et al., 2020a; Jin et al., 2020; Joshi et al., 2020; Kumar et al., 2020; Narkhede et al., 2020) and 3CLpro proteases (Gyebi et al., 2020; Ul Qamar et al., 2020), host ACE2 (Benarba and Pandiella, 2020; Maurya et al., 2020) and host TMPRSS2 (Benarba and Pandiella, 2020; Rahman et al., 2020). In addition to the docking scores, few of these studies have determined drug-like properties in silico (Narkhede et al., 2020) and have reported activity of compounds in functional assays in vitro (Jin et al., 2020). These investigations open new avenues for identifying naturally occurring novel lead compounds for the treatment of COVID-19, and for designing potential new chemical entities (NCEs) based on lead natural compounds. We focus on host RAS, viral RdRp, and ORF8 proteins as potential therapeutic targets using in silico molecular docking investigations.

\section{Targeting RAS for the treatment of COVID-19}

\subsection{Targeting ACE2: Strategy to attack the entry point and} its consequences

The virus is an obligatory intracellular parasite that relies on host biosynthetic factors and its replication and propagation environment. Thus, the concern in developing an antiviral drug is to 
develop an effective drug with selective toxicity for viruses and not the host. SARS-CoV-2 binds to ACE2 on the host cell membrane and, by endocytosis, enters into the cell. Small molecules targeting the viral binding to the host cells, namely ACE2 in SARS$\mathrm{CoV}-2$, and nucleoside analogs which interfere with viral replication, are potential therapeutics for treating viral diseases. Current pharmacotherapy for COVID-19 relies upon suppressing viral replication (example remdesivir), inflammation (example dexamethasone), immune response (example azithromycin), and blood coagulation (example enoxaparin). There are no known viral entry blockers that target host ACE2. Blocking viral entry into host cells may be the most effective strategy for prophylactic and therapeutic treatment of COVID-19. We have attempted to identify naturally occurring phytoconstituents that may target ACE2 and block viral entry using molecular docking studies. We also evaluated the molecular interactions of a select number of naturally occurring phytoconstituents at host AT1 and AT2 receptors, and SARS-CoV2 RdRp and ORF8 proteins using molecular docking.

\subsubsection{Molecular docking studies of various compounds with ACE2 \\ 3.1.1.1 Protein selection and preparation}

Five proteins ACE2 (PDB ID: 2AJF), ORF8 (PDBID: 6BB5), AT1 (PDBID:4ZUD), AT2 (PDBID: 4UNF) and RdRp (PDBID: 7BV2) were selected for docking protocols for identifying SARSCOV-2 ligands. The selection of PDB's was made on the basis of species and resolution. The target proteins were then imported from RCSB Protein Data Bank saved and prepared. The structure was preprocessed by adding hydrogens and checked for missing residues. The selection of water molecules was set at default, and protein was optimized, followed by energy minimization at the default setting. The docking grid was prepared, and docking performed.

\subsubsection{Ligand preparation}

Synthetic or phytoconstituents molecules were docked using the GLIDE module of Maestro 9.6 as per the Glide protocol given in Schrödinger. All the default parameters were used. For ligand preparation, the $\mathrm{pH}$ was $7.0 \pm 2.0$, the force field was OPLS3, and ionization was done using Epik. For protein preparation, the $\mathrm{pH}$ was $7.0 \pm 2.0$, the force field was OPLS3, ionization was done using Epikand, the water molecules within $5 \AA$ were kept, and rest were deleted.

\subsubsection{Molecular docking}

ACE2 (PDB ID: 2AJF), ORF8 (PDB ID: 6BB5), AT1 (PDB ID: 4ZUD), AT2 (PDB ID: 4UNF) and RdRp (PDB ID: 7BV2) were downloaded from the PDB database, and the potential binding sites were predicted by Prepwizard module of Schrödinger. A total of 30 compounds synthetic or natural origin were docked to the binding site of five proteins ACE2 (PDB ID: 2AJF), ORF8 (PDB ID: 6BB5), AT1 (PD BID: 4ZUD), AT2 (PD BID: 4UNF) and RdRp (PD BID: 7BV2) with Glide docking module of Schrödinger, which provides molecular mechanics algorithm along with shape analysis for accurately docking ligands into active sites. The docked poses were then analyzed using Schrödinger software's imaging tools.

\subsubsection{Molecular docking against ACE2}

For ACE2 docking, a selective ACE2 inhibitor GL1001 (MLN4760), was used as the positive control. GL1001 inhibits ACE2 ( IC $_{50}, 0.44 \mathrm{nM}$ ) with selectivity of $>5000$-fold as compared to $\mathrm{ACE}\left(\mathrm{IC}_{50}, 100 \mu \mathrm{M}\right)$ (Dales et al., 2002). Molecular docking for GL1001 revealed a docking score $-6.8 \mathrm{kcal} / \mathrm{mol}$ with interaction at Ala348, Asp350, Trp349, Asp382, and Arg393 amino acid residues of ACE2. However, the ACE inhibitor captopril interacted with different ACE2 amino acid residues (Tyr385, ASN394) with a markedly lower docking score of $-3.7 \mathrm{kcal} / \mathrm{mol}$. Although GL1001 (ORE1001) showed a good safety profile in phase 1 studies, the development of GL1001 for ulcerative colitis was unsuccessful. Subsequently, there was no consistent activity in developing a clinical candidate targeting ACE2.

At an earlier phase of COVID-19 pandemic, antimalarial drugs hydroxychloroquine and chloroquine were evaluated for potential efficacy in COVID-19 patients (Zhou et al., 2006). We found that hydroxychloroquine, chloroquine, and the active metabolites desethychloroquine, desethyhydroxychloroquine and bisdesethylchloroquine bound tightly to the active site of the ACE2 occupying the same binding pocket as GL1001. Hydroxychloroquine (docking score $=-8.8 \mathrm{kcal} / \mathrm{mol}$ ) occupies the ACE2 receptor cavity and makes hydrogen bonding with Phe40, Ala348, Asp350, Phe390, and His401.

Both chloroquine and hydroxychloroquine act by inhibiting glycosylation of host receptors, proteolytic processing, and endosomal acidification (Sanders et al., 2020). A recent in vitrostudy showed hydroxychloroquine was more potent than chloroquine against SARS-CoV-2 (Yao et al., 2020). Several clinical studies evaluating the action of chloroquine are ongoing, and findings from few clinical studies have been reviewed elsewhere (Chang and Sun, 2020; Pal et al., 2020). A comprehensive meta-analysis of clinical findings reports that the use of hydroxychloroquine was associated with increased mortality rates and increased risk of adverse events in SARS-CoV-2 patients (Chandrasekar et al., 2020). Based on 32 studies involving 29,192 participants, Cortegiani et al. (2020) concluded that chloroquine/ hydroxychloroquine confers no benefit in terms of mortality in hospitalized patients with COVID-19 (Cortegiani et al., 2020). Combination therapy with macrolide may be associated with harm, and postexposure prophylaxis with chloroquine/hydroxychloroquine may not reduce the rate of COVID-19 (Cortegiani et al., 2020). Although the docking of hydroxychloroquine was better than the reference compound GL-1001, the narrow therapeutic index associated with the cardiotoxicity and controversy regarding the efficacy and safety of hydroxychloroquine for prophylactic treatment of COVID-19 tempted us to explore potential natural products-based ACE2 inhibitors.

Herbal drugs are in use for the treatment of various diseases, including respiratory viral infections. The significant advantage of using herbs in viral respiratory infections is due to their potent anti-inflammatory and immunostimulatory action (Patwardhan et al., 2020). Some of the active phytoconstituents in medicinal plants have inhibitory action on coronaviruses (Boukhatem and Setzer, 2020; Mani et al., 2020), however determination of functional actions on ACE2 is critical to elucidate agonist/activation or inhibitor/antagonist. Considering the pathogenesis of COVID19, we identified some Indian medicinal plants with potent antiinflammatory, immunomodulatory, and antiviral activities for de- 
Table 1. Docking scores and binding free energies of phytoconstituents interacting with ACE2 and interacting amino acids.

\begin{tabular}{|c|c|c|c|c|}
\hline & LigandPhytoconstituent & $\begin{array}{l}\text { ACE2 Docking } \\
\text { scorekcal/mol }\end{array}$ & ACE2amino acids interactingwith the ligand & $\begin{array}{c}\text { Binding free } \\
\text { energykcal/mol }\end{array}$ \\
\hline Positive control & GL-1001 & -6.8 & Ala348, Trp349, Asp350, Asp382, Arg393 & -60.2 \\
\hline Negative control & Captopril & -3.7 & Tyr385, ASN394 & -25.5 \\
\hline 1 & Rutin & -11.5 & $\begin{array}{c}\text { Ala348, Asp350, Arg393 } \\
\text { Ser44, Ser47, Phe390, Asn394 }\end{array}$ & -78.2 \\
\hline 2 & Verbascoside & -10.2 & $\begin{array}{c}\text { Ala348, Asp350, Asp382 } \\
\text { Glu375, His378, Phe390, Asn394, Glu402 }\end{array}$ & -90.4 \\
\hline 3 & Hesperidin & -9.5 & $\begin{array}{c}\text { Ala348, } \mathbf{A s p 3 5 0} \\
\text { Trp69, Tyr385 }\end{array}$ & -70.3 \\
\hline 4 & Luteolin 7-O-glucoside & -9.3 & $\begin{array}{c}\text { Ala348, Arg393 } \\
\text { Glu375, Phe390, Glu402 }\end{array}$ & -65.3 \\
\hline 5 & Naringin & -9.2 & Ala348, Arg393 & -65.2 \\
\hline 6 & Epigallocatechin gallate & -8.6 & $\begin{array}{c}\text { Ala348, Asp350, Asp382, Arg393 } \\
\text { Phe390 }\end{array}$ & -72.0 \\
\hline 7 & Apigenin-7- $O$-glucoside & -8.1 & $\begin{array}{l}\text { Ala348, Arg393 } \\
\text { Glu375, Asn394 }\end{array}$ & -59.2 \\
\hline 8 & Hesperetin & -7.3 & $\begin{array}{l}\text { Ala348, Arg393 } \\
\text { Phe390, Asn394 }\end{array}$ & -57.5 \\
\hline 9 & Quercetin & -7.0 & $\begin{array}{c}\text { Ala348, Arg393 } \\
\text { Phe } 390\end{array}$ & -57.5 \\
\hline 10 & Naringenin & -6.4 & $\begin{array}{l}\text { Ala348 } \\
\text { Phe390 }\end{array}$ & -51.1 \\
\hline 11 & Dioscin & -6.4 & Asp350 & -57.0 \\
\hline 12 & Kaempferol & -6.3 & $\begin{array}{l}\text { Ala348, Arg393 } \\
\text { Phe390, Asn394 }\end{array}$ & -52.6 \\
\hline 13 & Apigenin & -6.2 & $\begin{array}{r}\text { Ala348 } \\
\text { Phe390 }\end{array}$ & -50.6 \\
\hline 14 & Luteolin & -6.0 & $\begin{array}{c}\text { Ala348, Arg393 } \\
\text { Phe } 390\end{array}$ & -65.3 \\
\hline 15 & Solanine & -6.0 & $\begin{array}{l}\text { Ala348 } \\
\text { Glu402 }\end{array}$ & -42.2 \\
\hline 16 & Solamargine & -5.6 & Phe390 & -47.4 \\
\hline 17 & Galangin & -5.3 & $\begin{array}{c}\text { Arg393 } \\
\text { Phe390, Asn394 }\end{array}$ & -44.8 \\
\hline 18 & Acalyphin & -5.2 & $\begin{array}{c}\text { Asp350, Arg393 } \\
\text { Asn394 }\end{array}$ & -46.5 \\
\hline 19 & Solasodine & -4.8 & Phe390 & -42 \\
\hline 20 & Lantadene A & -4.5 & Ala348, Asp350 & -54.8 \\
\hline 21 & Oleanolic acid & -4.4 & $\begin{array}{r}\text { Ala348 } \\
\text { Asn394 }\end{array}$ & -29.1 \\
\hline 22 & Lantadene C & -4.0 & Asp350 & -52.2 \\
\hline 23 & Lantadene B & -3.6 & Tyr369 & 50.0 \\
\hline 24 & Ricinine & -3.2 & Tyr385 & -20.7 \\
\hline 25 & Solasonine & -2.6 & None & -30.1 \\
\hline
\end{tabular}

ACE2 amino acids interacting with GL-1001, a selective ACE2 inhibitor, are given in bold.

veloping potential treatment of COVID-19. These plants identified were Solanum nigrum, Euphorbia prostrata, Acalypha indica, Lantana camara and Ricinus communis. A literature search to identify the phytoconstituents of these plants revealed that they contain flavonoids, flavonoid glycosides (Huang et al., 2010; Patil and Limaye, 2017), triterpenoids (Ghisalberti, 2000), steroidal glycoalkaloids (Gu et al., 2018) and other compounds of different classes (Herbert et al., 1991; Nahrstedt et al., 1982; Tai et al., 2018). Furthermore, it has been reported that flavonoids can bind to the SARS-CoV-2 S protein, a viral surface glycoprotein required for initial attachment and internalization within host cells (Rane et al., 2020). Flavonoids, in particularly, luteolin, quercetin, apigenin, amentoflavone, epigallocatechin (EGC), epigallocatechin gallate (EGCG), gallocatechin gallate (GCG) and kaempferol were reported to inhibit the proteolytic activity of SARS-CoV3CLpro(Nguyen et al., 2012; Ryu et al., 2010) and 3a 


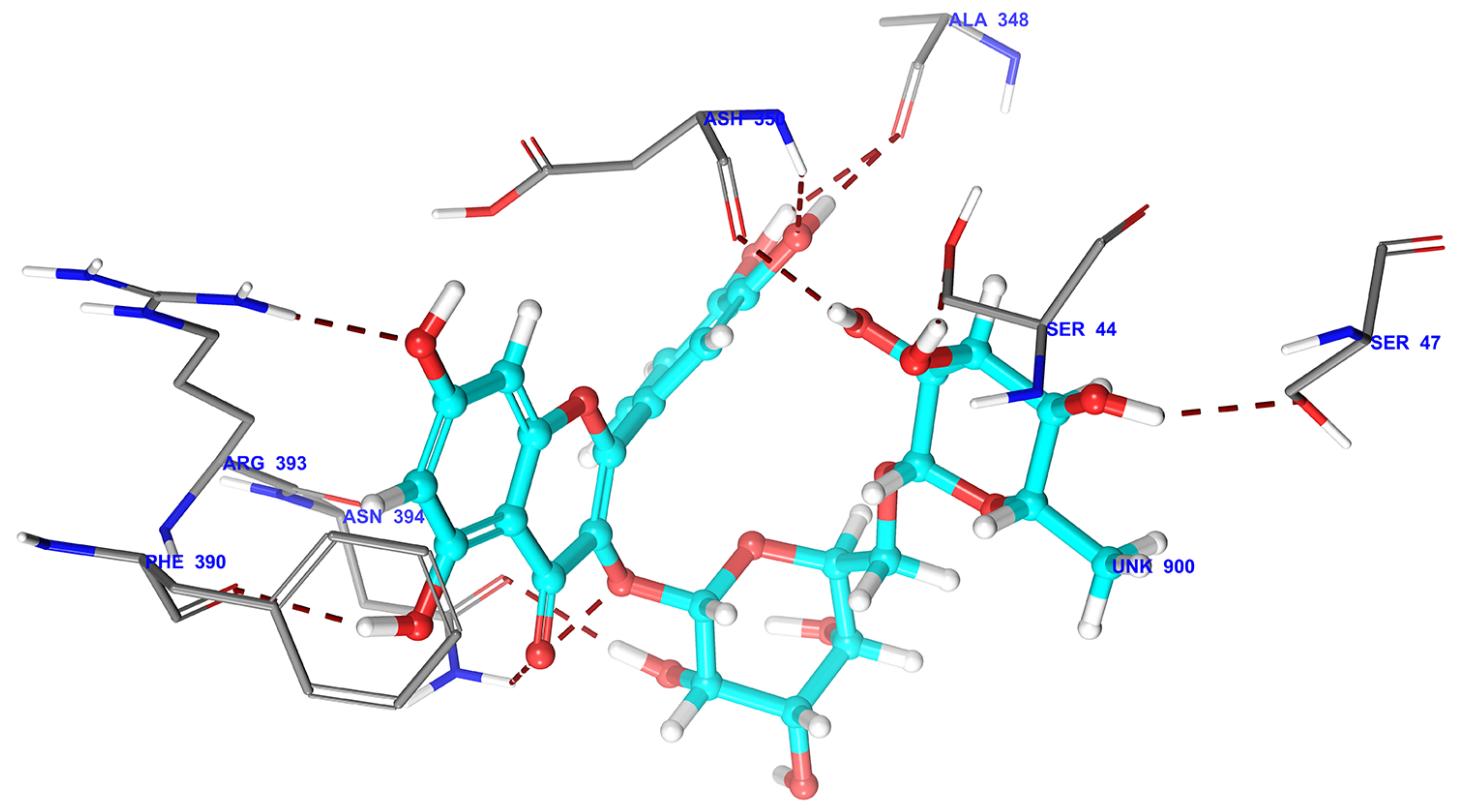

Fig. 2. 3D docking pose of rutin into the ACE2 receptor catalytic domain (Pdbid: 2ajf) showing binding interaction with key amino acid residues of backbone protein. The backbone amino acid residues highlighted with grey colour. Binding interaction (hydrogen bonding) depicted with red dashed lines.

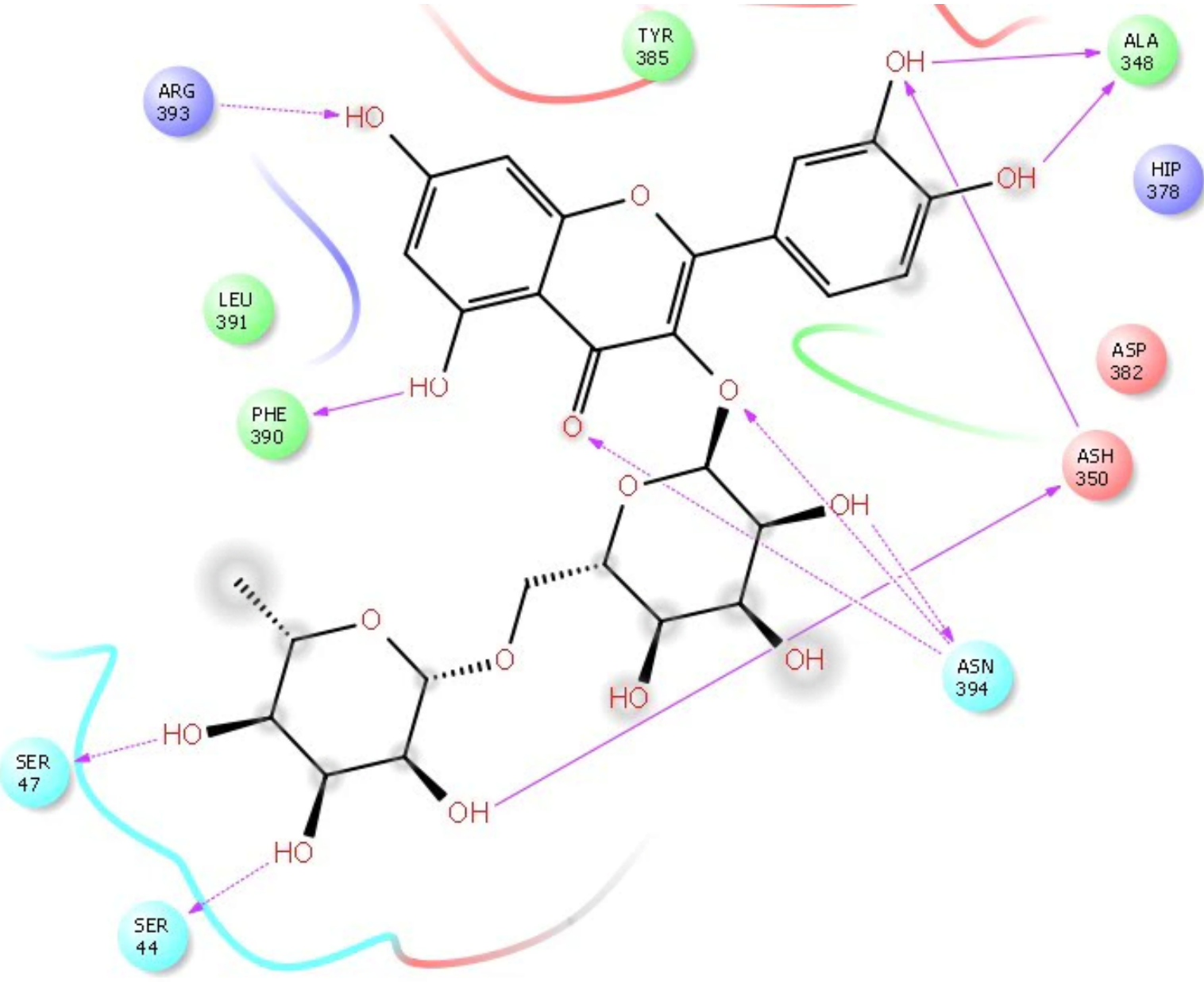

Fig. 3. D Ligplot interaction of rutin against ACE2 receptor catalytic domain (Pdbid-2ajf). The pose was in 2D form and all the interactions were depicted by red solid lines, hydrophobic amino acid residue denoted by green colour, positive charge residue denoted by blue colour, charged negative residue denoted by red colour, polar residue were denoted by sky blue colour. 
channel protein of coronavirus (Schwarz et al., 2014). Certain flavonoids viz., luteolin, quercetin, rutin, kaempferol, and apigenin showed ACE inhibitory activity (Guerrero et al., 2012). In addition to flavonoids, we have also docked certain other compounds of phytochemical groups like triterpenoids, steroidal glycoalkaloids, phenolic compounds since these were major chemical constituents of the antiviral plants mentioned above'. Molecular docking study was also carried out for selected steroidal glycoalkaloids: solamargine, solasonine, solasodine, solanine; flavonoids: rutin, naringenin, luteolin, myricetin, quercetin, apigenin, kaempferol and hesperetin, hesperidin, apigenin-7- $O$-glucoside, luteolin-7- $O$ glucoside; triterpenoids: Lantadene A, B, C, oleanolic acid, acalyphin, ricinine, dioscin, and epigallocatechin gallate, verbascoside.

Results of these docking studies revealed that the compounds rutin, verbascoside, and hesperidin bound tightly at the active site of ACE2 (Table 1). The compound rutin (docking score: $-11.5 \mathrm{kcal} / \mathrm{mol}$ ) well occupied the receptor cavity through hydrogen bonding with Ala348, Asp350, Phe390, Ser44, Ser47 Arg393, Asn394 (Fig. 2 and 3) and verbascoside (docking score: $10.2 \mathrm{kcal} / \mathrm{mol}$ ) showed hydrogen bonding interaction with Ala348, Asp350, Asp382, Phe390, Glu375, His37, Asn394, and Glu402, whereas hesperidin (docking score: $-9.5 \mathrm{kcal} / \mathrm{mol}$ ) showed hydrogen bonding interaction with Ala348, Asp350, Trp69, and Tyr385. The binding free energy of these interactions is strong.

ACE2-Phytoconstituent molecular docking studies revealed that Ala348 and Asp350 or Arg393 of ACE2 interact with several flavonoids and may be important in modulating ACE2 activity. Phe390 also interacts many phytoconstituents via hydrogen bonding. Recently, hesperidin has been proposed to be useful in prophylaxis for COVID-19 potentially inhibiting ACE2, cytokine storm and blood coagulation (Haggag et al., 2020; Huang et al., 2020; Wu et al., 2020). Phytoconstituents also interacts with Ala348, Arg393, Phe390, and Asn394. The interaction of Asp382 also observed with verbascoside and epigallocatechin gallate.

ACE2 catalytic site and viral S-protein binding site are reported to be distinct, and there may be an allosteric interaction between these two sites (Gross et al., 2020; Li et al., 2005; Rushworth et al., 2008). Some of the phytoconstituents may interact with both the catalytic and S-protein binding sites, whereas others may interact with one of the two sites. Further investigation of effect of phytoconstituents on the ACE2 catalytic and viral entry into cells using cell-based functional assays may provide insights into phytoconstituents that may be useful for the treatment of COVID-19.

\subsubsection{Molecular docking against AT1 and AT2 receptors}

Encouraged by the results of the phytochemicals on ACE2 interaction, we carried out the docking studies with AT1 and AT2 receptors. To confirm our docking approach, we have used AT1 antagonist, Olmesartan, and AT2 antagonist, PD12377, as pharmacological controls. Olmesartan showed a docking score of $-8.9 \mathrm{kcal} / \mathrm{mol}$ and -6.5 at AT1, and AT2 receptors, respectively. On the other hand, PD12377 showed a docking score of -4.9 and $-6.7 \mathrm{kcal} / \mathrm{mol}$ at AT2 receptors, respectively, validating our docking approach.

The compounds solanine, rutin, quercetin, hesperetin, epigallocatechin gallate, apigenin-7-O-glucoside, luteolin-7-O-glucoside, verbascoside, hesperidin and naringin showing good binding affinity and docking score better than $-6.0 \mathrm{kcal} / \mathrm{mol}$ against ACE2, were further selected for docking against AT1and AT2 receptors (Table 2).

After docking against the AT1 and AT2 receptor of selected compounds, we found all compounds showed good binding affinity against both the receptors, which is higher than $-7.0 \mathrm{kcal} / \mathrm{mol}$. Moreover, rutin secured a high docking score among all the compounds in docking study against AT1 and AT2 receptors. It forms hydrogen bond interactions with AT1 receptor protein through Tyr35, Thr88, Arg167, Asp263, Tyr184, Gln267, Phe182, and while making pi-pi stacking interaction with Tyr87. The docking score of rutin against the AT1 receptor is $-12.60 \mathrm{kcal} / \mathrm{mol}$ (Fig. 4 and 5). Interestingly, the docking results of selected compounds at the AT2 receptor also show a high docking score of rutin because of its ability to form hydrogen bonding with amino acid residues like Ser208, Asp279, Lys215, Arg182, and pi-pi stacking with the Phe272. The docking score of the highest-scoring compound rutin against the AT2 receptor was $-11.9 \mathrm{kcal} / \mathrm{mol}$ (Fig. 6 and 7).

Interestingly, the docking results of selected compounds at the AT2 receptor also show a high docking score of rutin because of its ability to form hydrogen bonding with amino acid residues like Ser208, Asp279, Lys215, Arg182, and pi-pi stacking with the Phe272. The docking score of the highest-scoring compound rutin against the AT2 receptor was $-11.9 \mathrm{kcal} / \mathrm{mol}$ (Fig. 6 and 7).

In the docking study results almost all the phytoconstituents showed similar binding interaction with Tyr35 and Arg167 as shown by the standard at AT1 receptor. However, most of the phytoconstituents showed some marked affinity towards Arg182 and Lys215 amino acids at AT2 receptor in a same way as depicted by the standard.

Docking studies revealed that phytoconstituents interacts with ACE2, AT1 and AT2 receptors of the RAS system. Both ACE and ACE2 are involved in the hydrolysis of bradykinin which also contributes to disturbance in RAS homeostasis, inflammatory response and COVID-19 pathology. Inhibition of ACE and ACE2 causes increase in the circulating levels of bradykinin. Moreover, neprilysin mainly due its hydrolytic action on bradykinin and angiotensin 1-7 modulates RAS. Considering that there is no approved bradykinin receptor antagonist and neprilysin inhibitor, evaluating the action of phytoconstituents on bradykinin and neprilysin pathways will provide a more comprehensive understanding of RAS homeostasis, and its modulation in inflammatory diseases and development of therapeutics (Roche and Roche, 2020).

Upon entry into host, SARS-CoV2 triggers both innate and adaptive immune responses with the accumulation of activated monocytes, macrophages, and neutrophils, leading to uncontrolled inflammation due to the release cytokines and chemokines (Del Valle et al., 2020; Nathan, 2020; Sallenave and Guillot, 2020; Vabret et al., 2020). This cytokine storm causes severe lung inflammation accompanied by inflammatory damage to multipleorgans, and vascular thrombosis, which causes death in severely ill COVID-19 adult patients and children (Capone et al., 2020; Crisafulli et al., 2020; Jose and Manuel, 2020; Mahmudpour et al., 2020; Mehta et al., 2020; Rowley, 2020; Soy et al., 2020; Ye et al., 2020). Kinase inhibitors (baricitinib, imatinib, dasatinib, tramitinib, selumetinib) due to their anti-inflammatory actions approved for other inflammatory diseases are being investigated for COVID- 
Table 2. Docking scores and binding free energies of phytoconstituents interacting with AT1 or AT2 and interacting amino acids.

\begin{tabular}{|c|c|c|c|c|c|c|c|}
\hline & $\begin{array}{c}\text { Ligand- } \\
\text { Phytoconstituent }\end{array}$ & $\begin{array}{l}\text { AT1 Docking } \\
\text { score kcal/mol }\end{array}$ & $\begin{array}{c}\text { Binding free } \\
\text { energy against } \\
\text { AT1kcal/mol }\end{array}$ & $\begin{array}{c}\text { AT1 amino acids interacting } \\
\text { with the ligand }\end{array}$ & $\begin{array}{l}\text { AT2 Docking } \\
\text { score kcal/mol }\end{array}$ & $\begin{array}{c}\text { AT2 amino acids } \\
\text { interacting with the } \\
\text { ligand }\end{array}$ & $\begin{array}{c}\text { Binding free } \\
\text { energy against } \\
\text { AT2kcal/mol }\end{array}$ \\
\hline & $\begin{array}{c}\text { OlmesartanAT1 } \\
\text { antagonist }\end{array}$ & -8.9 & -84.3 & Tyr35, Trp84, Thr88,Arg167 & -6.5 & Arg182,Lys215, Trp100 & -78.3 \\
\hline & $\begin{array}{c}\text { PD12377AT2 } \\
\text { antagonist }\end{array}$ & -4.9 & -85.6 & Tyr87, Tyr92 & -6.7 & $\begin{array}{c}\text { Trp100, Phe129, } \\
\text { Arg182, } \\
\text { Lys215, Phe272 }\end{array}$ & -82.9 \\
\hline 1 & Rutin & -12.6 & -95.2 & $\begin{array}{r}\text { Tyr35, Thr88, Arg167 } \\
\text { Tyr87, Phe182, Tyr184, Asp263, }\end{array}$ & $\begin{array}{r}-11.9 \\
G \ln 267\end{array}$ & $\begin{array}{l}\text { Arg182, Lys215, Phe272 } \\
\text { Ser208, Asp279 }\end{array}$ & -91.5 \\
\hline 2 & Verbascoside & -12.3 & -91.7 & $\begin{array}{c}\text { Arg167 } \\
\text { Tyr184,Trp253, Gln257 Asp263 }\end{array}$ & -11.6 & $\begin{array}{r}\text { Arg182, Lys215 } \\
\text { Tyr108, Thr276, Asp279, }\end{array}$ & $\begin{array}{r}-94.8 \\
\operatorname{Trp} 283\end{array}$ \\
\hline 3 & Hesperidin & -11.6 & -90.3 & $\begin{array}{c}\text { Tyr35 } \\
\text { Ser16, Cys18, Ala21, Tyr87 }\end{array}$ & -10.2 & $\begin{array}{l}\text { Arg182, Lys215 } \\
\text { Thr276, Asp279 }\end{array}$ & -91.0 \\
\hline 4 & $\begin{array}{l}\text { Luteolin } \\
\text { 7- } O \text {-glucoside }\end{array}$ & -10.5 & -76.8 & $\begin{array}{c}\text { Tyr35 } \\
\text { Cys180, Tyr292 }\end{array}$ & -9.7 & $\begin{array}{c}\text { Arg182, Lys215 } \\
\text { Thr125 }\end{array}$ & -68.0 \\
\hline 5 & Naringin & -10.7 & -84.1 & $\begin{array}{c}\text { Tyr35, Thr88, Arg167 } \\
\text { Pro19, Ala21, Arg23, Tyr87 }\end{array}$ & -10 & $\begin{array}{c}\text { Lys215 } \\
\text { Cys195, Thr276, Asp279 }\end{array}$ & -83.9 \\
\hline 6 & $\begin{array}{l}\text { Epigallocatechin } \\
\text { gallate }\end{array}$ & -7.2 & -72.8 & $\begin{array}{c}\text { Arg167 } \\
\text { Ala21, Arg23, Tyr87, Tyr92, As! }\end{array}$ & p263 & $\begin{array}{c}\text { Lys215, Phe272 } \\
\text { Thr178 }\end{array}$ & -78.2 \\
\hline 7 & $\begin{array}{l}\text { Apigenin-7-O- } \\
\text { glucoside }\end{array}$ & -11.1 & -74.9 & $\begin{array}{c}\text { Arg167 } \\
\text { Ala21, Tyr87, Asp281 }\end{array}$ & -10.2 & $\begin{array}{c}\text { Arg182 } \\
\text { Tyr51, Thr125 }\end{array}$ & -74.3 \\
\hline 8 & Hesperetin & -8.0 & -50.5 & $\begin{array}{c}\text { Arg167 } \\
\text { Tyr87 }\end{array}$ & -7 & $\begin{array}{c}\text { Lys215, Phe272 } \\
\text { Thr178 }\end{array}$ & -57.7 \\
\hline 9 & Quercetin & -8.4 & -55.3 & $\begin{array}{c}\text { Tyr35 } \\
\text { Ala21, Tyr87, Tyr92 }\end{array}$ & -7.5 & $\begin{array}{c}\text { Lys215, Phe272 } \\
\text { Thr178 }\end{array}$ & -54.2 \\
\hline 10 & Naringenin & -8.0 & -45.5 & $\begin{array}{c}\text { Arg167 } \\
\text { Tyr87 }\end{array}$ & -7.7 & $\begin{array}{c}\text { Thr125 } \\
\text { Arg182 }\end{array}$ & -50 \\
\hline 11 & Dioscin & -10.0 & -58.8 & Tyr87 & -8.2 & Thr125 & -54.2 \\
\hline 12 & Kaempferol & -7.0 & -46.5 & $\begin{array}{c}\text { Tyr35, Arg167 } \\
\text { Tyr87 }\end{array}$ & -7.3 & $\begin{array}{c}\text { Phe272 } \\
\text { Thr125, Ile304 }\end{array}$ & -50.3 \\
\hline 13 & Apigenin & -7.8 & -45.3 & Arg167 & -7.7 & $\begin{array}{c}\text { Arg182 } \\
\text { Thr125 }\end{array}$ & -48.5 \\
\hline 14 & Luteolin & -9.0 & -47.4 & Arg167 & -7.3 & $\begin{array}{c}\text { Lys215, Phe272 } \\
\text { Thr178 }\end{array}$ & -52.8 \\
\hline 15 & Solanine & -8.4 & -33.5 & None & -8.9 & Arg182 & -50.1 \\
\hline
\end{tabular}

19 (Dyall et al., 2014; Richardson et al., 2020a; Schrader et al., 2018; Stebbing et al., 2020; Troiani et al., 2012; Zhang et al., 2020). Anticoagulants (warfarin, dabigatran, betrixaban, and rivaroxaban) are also being evaluated for the treatment of thrombosis in COVID-19 patients (www.clinicaltrials.gov). The main challenge faced by the clinicians while using anticoagulant drugs in treating COVID19 patients is the possible interaction of anticoagulants with most antiviral drugs.

\section{Targeting viral RNA-dependent RNA polymerase (RdRp): Step towards inhibition of viral replication}

RNA-dependent RNA polymerase (RdRp) in the viral nonstructural protein 12 (nsp12) has been a target for drug development. Many studies are evaluating nucleoside and nucleotide analogs for the repurposing. Based on the initially promising clinical findings, remdesivir has recently been approved by the FDA for the treatment of COVID-19. It is a broad-spectrum antiviral drug initially developed by Gilead Sciences in 2009 for hepatitis C. It did not work against hepatitis $\mathrm{C}$ and then repurposed for Ebola virus (Jacobs et al., 2016). It is effective against many other viruses, including coronavirus (Lo et al., 2017). Remdesivir, an adenosine nucleo- 


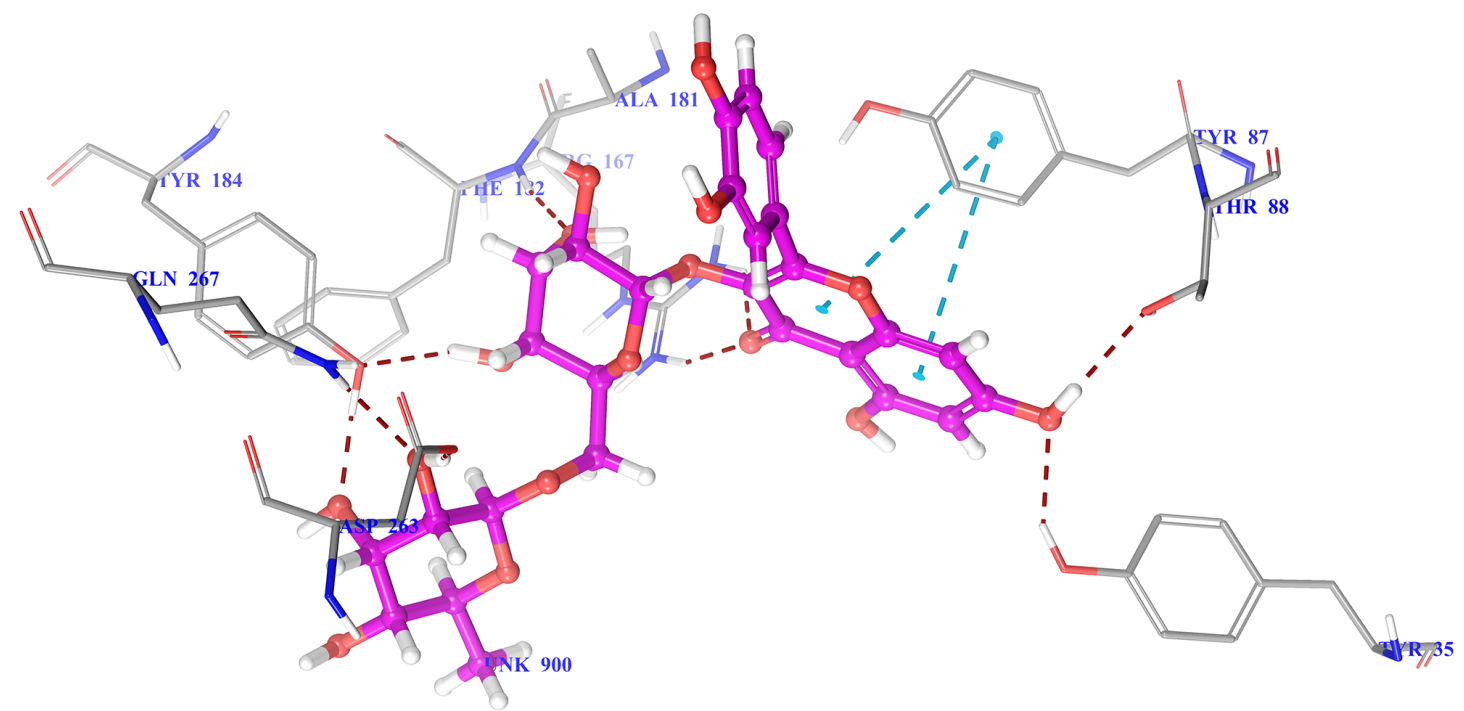

Fig. 4. 3D docking pose of rutin into the AT1 receptor (Pdbid-4zud) showing binding interaction with key amino acid residues of backbone protein. The backbone amino acid residues highlighted with grey colour while rutin highlighted by green colour. Binding interaction (hydrogen bonding) depicted with red dashed lines. Pi-pi stacking interaction was denoted by blue dashed lines.

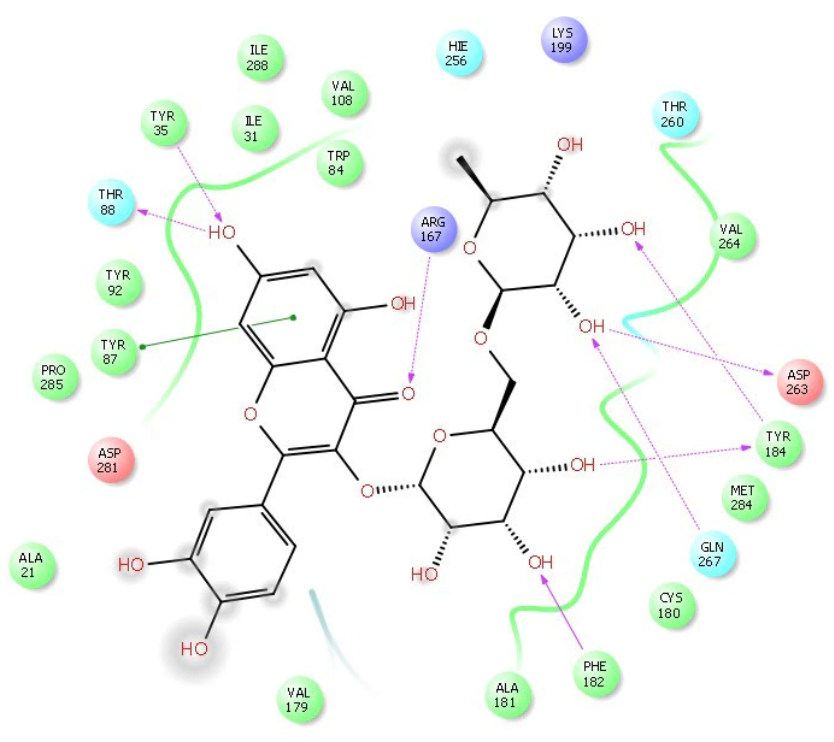

Fig. 5. 2D Ligplot interaction of rutin docked in to the AT1 receptor catalytic domain (Pdbid-4zud). The pose was in 2D form and all the interactions were depicted by red solid lines, hydrophobic amino acid residue denoted by green colour, positive charge residue denoted by blue colour, charged negative residue denoted by red colour, polar residue were denoted by sky blue colour.

side triphosphate analog, is metabolized in the cell, and the active remedisvir metabolite interferes with the viral RdRp that evades proofreading by the viral exoribonuclease (ExoN) in nsp14, ultimately causing a decrease in viral RNA production (Ferner and Aronson, 2020). The RdRp of MERS-CoV, SARS-CoV-1, and SARS-CoV-2 arrest of RNA synthesis occurs after the incorporation of three additional nucleotides (Lo et al., 2017). Hence, remdesivir is a direct-acting antiviral agent that works as a delayed chain terminator (Tchesnokov et al., 2019). Remdesivir treatment produced clinical improvement in two-third of patients, but the mor-

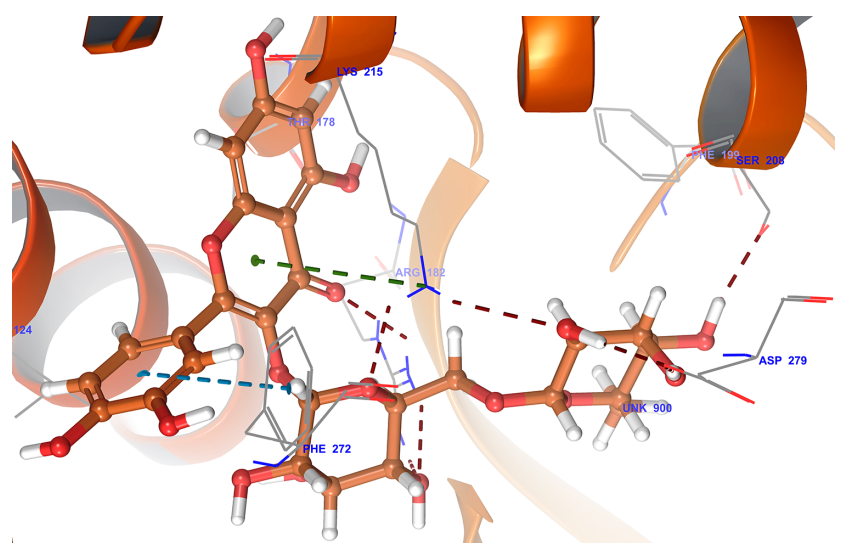

Fig. 6. 3D docking poses of rutin in to the AT2 receptor catalytic domain (Pdbid-4unf) showing binding interaction with key amino acid residues of backbone protein. The backbone amino acid residues highlighted with grey colour while rutin highlighted by brown colour. Binding interaction (hydrogen bonding) depicted with red dashed lines. Pi-pi stacking interaction was denoted by blue dashed lines.

tality rate was similar to the placebo group (Antinori et al., 2020; Beigel et al., 2020; Grein et al., 2020; Wang et al., 2020). The antiviral activity of remdesivir is not only marginal but also variable.

In search of other potential antiviral drugs, a randomized, controlled, open-label trial was conducted among COVID-19 patients with lopinavir-ritonavir (400 mg and $100 \mathrm{mg}$, respectively) for 14 days (Cao et al., 2020). But no benefit was observed with lopinavirritonavir treatment beyond standard care. Nafamostat mesylate, a serine protease inhibitor showed promising effect e against SARSCoV-2 infection of lung cells (Hoffmann et al., 2020). Ribavirin also supports its potential to significantly impact the treatment of SARS-CoV-2 infections due to low cost and wide availability. An adjuvant therapy of Oseltamivir gave promising results in patients coinfected with novel coronavirus 2019 and influenza virus in Wuhan, China (Ding et al., 2013). Penciclovir, an acyclic nu- 
Table 3. Docking scores and binding free energies of phytoconstituents interaction with viral RdRp and ORF8 interacting amino acids.

\begin{tabular}{|c|c|c|c|c|c|c|c|}
\hline & $\begin{array}{l}\text { Ligand Phyto- } \\
\text { constituent }\end{array}$ & $\begin{array}{l}\text { RdRp Docking } \\
\text { score kcal/mol }\end{array}$ & $\begin{array}{c}\text { Binding free energy } \\
\text { against RdRp } \\
\text { kcal/mol }\end{array}$ & $\begin{array}{l}\text { RdRp amino acids } \\
\text { interacting with the } \\
\text { ligand }\end{array}$ & $\begin{array}{l}\text { ORF8 Docking } \\
\text { score kcal/mol }\end{array}$ & $\begin{array}{l}\text { ORF8 amino acids } \\
\text { interacting with the } \\
\text { ligand }\end{array}$ & $\begin{array}{c}\text { Binding free } \\
\text { energy against } \\
\text { ORF8 kcal/mol }\end{array}$ \\
\hline & $\begin{array}{c}\text { Uridine } \\
\text { Triphosphate }\end{array}$ & -6.7 & -56.8 & $\begin{array}{c}\text { Lys551, Arg553, Arg555, } \\
\text { Lys621, Asp760 }\end{array}$ & ND & ND & ND \\
\hline & $\begin{array}{l}\text { Thymidine } \\
\text { derivative }\end{array}$ & -6.5 & -53.2 & Arg553, Cys622 & ND & ND & ND \\
\hline & $\begin{array}{l}\text { Remedisvir } \\
\text { metabolite }\end{array}$ & -6.7 & -61.5 & $\begin{array}{l}\text { Lys551, Arg555 } \\
\text { Ser549 }\end{array}$ & ND & ND & $\mathrm{ND}$ \\
\hline \multirow[t]{2}{*}{1} & Rutin & -9.0 & -90.6 & Arg555 & -10.9 & $\begin{array}{c}\text { Tyr42, His45, His } 58, \\
\text { Lys61, His } 87\end{array}$ & -68.9 \\
\hline & & & & $\begin{array}{c}\text { Ile548, Arg553, Asp623, } \\
\text { Asp760 }\end{array}$ & & & \\
\hline 2 & Verbascoside & -7.4 & -132.7 & $\begin{array}{c}\text { Lys551, Arg555, } \\
\text { Asp760 } \\
\text { Asp618, Cys622 }\end{array}$ & -9.9 & Lys61, Lys90 & -72.7 \\
\hline 3 & Hesperidin & -10.0 & -98.1 & Arg555 & -14.5 & $\begin{array}{l}\text { Phe43, His45, His58, } \\
\text { Lys61, His87, Asn97 }\end{array}$ & -97.5 \\
\hline 4 & $\begin{array}{l}\text { Luteolin } \\
\text { 7-O-glucoside }\end{array}$ & -8.5 & -102 & $\begin{array}{l}\text { Lys545, Ile548, Asp845 } \\
\text { Ile548, Ser759, Arg836 }\end{array}$ & -13.1 & His58, His87, Tyr42 & -74.4 \\
\hline 5 & Naringin & -9.6 & -90.9 & $\begin{array}{c}\text { Asp760 } \\
\text { Ser549, Tyr619, Asp623, }\end{array}$ & -11.2 & His58, His87, Lys90 & -63.2 \\
\hline 6 & $\begin{array}{l}\text { Epigallocatechin } \\
\text { gallate }\end{array}$ & -5.2 & -103.7 & Ile548, Ser814 & -11.6 & Tyr42, His58 & -54.2 \\
\hline 7 & $\begin{array}{l}\text { Apigenin-7-O- } \\
\text { glucoside }\end{array}$ & -8.6 & -90.7 & Arg555, Asp760 & -12.6 & Tyr42, His58, His87 & -74.8 \\
\hline & & & & Ile548 & & & \\
\hline 8 & Hesperetin & -6.1 & -61.5 & $\begin{array}{l}\text { Arg555 } \\
\text { Ser682 }\end{array}$ & -9.7 & His87 & -51.5 \\
\hline 9 & Quercetin & -7.8 & -62.6 & $\begin{array}{l}\text { Arg555 } \\
\text { Ser682 }\end{array}$ & -10.5 & His87 & -53.7 \\
\hline 10 & Naringenin & -6.4 & -43.6 & Ser682 & -9.3 & His58, His87 & -46.9 \\
\hline 11 & Dioscin & -5.9 & -100 & Tyr619 & -4.2 & Lys90 & -40.1 \\
\hline 12 & Kaempferol & -5.7 & -53.7 & Arg555 & -9.8 & His87 & -50.1 \\
\hline 13 & Apigenin & -5.5 & -52.1 & $\begin{array}{l}\operatorname{Arg555} \\
\text { Ser682 }\end{array}$ & -9.0 & His87 & -52.1 \\
\hline 14 & Luteolin & -6.4 & -54.1 & $\begin{array}{l}\operatorname{Arg555} \\
\text { Ser682 }\end{array}$ & -10.0 & His87 & -52.2 \\
\hline 15 & Solanine & -6.1 & -102.9 & Ser682 & -5.5 & His87 & -51.2 \\
\hline 16 & Solamargine & -10.8 & -72.8 & Tyr619 & -4.7 & $\operatorname{Trp} 42$ & -43.2 \\
\hline 17 & Galangin & -5.6 & -52.1 & Arg555 & -9.8 & Tyr42, His58, His87 & -51.2 \\
\hline 18 & Acalyphin & -5.6 & -46.6 & $\begin{array}{c}\text { Asp760 } \\
\text { Asp618, Lys621 }\end{array}$ & -6.6 & His 87 & -37.5 \\
\hline 19 & Solasodine & -4.2 & -58.6 & Asn691 & -2.0 & Leu91 & -16.9 \\
\hline 20 & Oleanolic acid & -3.0 & -58.2 & Ser549, Tyr619 & -1.2 & Lys 90 & -69.2 \\
\hline
\end{tabular}

SARS-CoV-2 RdRp amino acids interacting with uridine triphosphate, are given in bold.

cleoside analog, showed marked efficacy when used in combined antiviral therapy against SARS-CoV-2 infection. In an open-label control study, the favipiravir exerted better treatment effects on COVID-19 patients (Cai et al., 2020). Other antiviral drugs like Ganciclovir, Tenofovir, Dolutegravir, Atazanavir, Asunaprevir, Elbasvir, and Sofosbuvir are being proposed and tested but not found so effective against SARS-CoV-2 (Tan et al., 2004). Hence, it remains an unmet need for an efficacious and safe RdRp inhibitor.

Besides antivirals, clinical investigations are ongoing to repurpose non-antiviral drugs, such as Rapamycin and Tiotropium, which may act by inhibiting the replication of SARS-CoV-2 like in the case of HIV (Nicoletti et al., 2011). The observed hyperacti- 


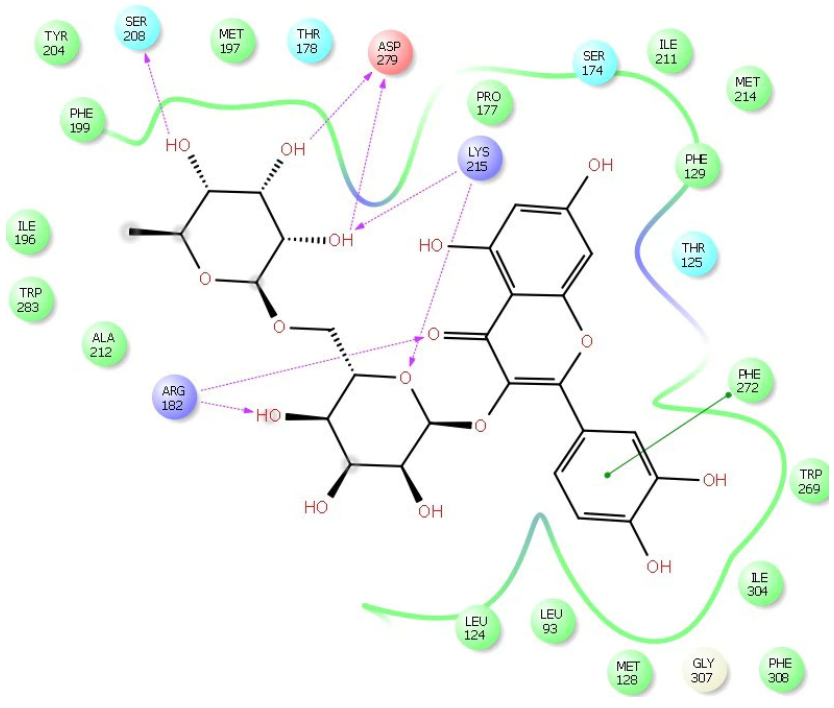

Fig. 7. 2D Ligplot interaction of rutin docked in to the AT2 receptor catalytic domain (Pdbid-4unf). The pose was in 2D form and all the interactions were depicted by red solid lines, hydrophobic amino acid residue denoted by green colour, positive charge residue denoted by blue colour, charged negative residue denoted by red colour, polar residue were denoted by sky blue colour.

vation of the immune response in COVID-19 involves dysregulation of mTOR molecule. mTOR plays a critical role in immuneregulation and immune-tolerance control pathways. The ability of mTOR inhibitors to suppress early stages of viral replication, reduce mRNA translation, ribosome biogenesis, protein synthesis, mitochondrial metabolism, and viral replication suggest potential clinical benefit from mTOR inhibitors (Ramaiah, 2020).

Targeting cellular mTOR results in antiviral action in HIV infection, specific mTOR inhibitors, including Rapamycin and Everolimus, may have a beneficial outcome in COVID-19 subjects. (Fagone et al., 2020; Heredia et al., 2015; Nicoletti et al., 2011; Zheng et al., 2020). Moreover, using the molecular transformer-drug-target interaction prediction model, (Kang et al., 2020) showed that SARS-CoV-2 infection strongly activates cytokine and immune system, including upregulation of TNF and $\mathrm{NF} \kappa \mathrm{B}$-signaling pathways, similar to those observed in patients with chronic obstructive pulmonary disease (COPD). Accordingly, tiotropium reduces the expressions of IL1B, IL6, IL8, RELA, NFKB1, and TNF in vitro or in vivo may be effective for COVID19 patients due to its effect on viral replication and suppression of cytokine suppression action (Kang et al., 2020). It has also been reported that if the production of cross-reactive antibodies associated with antibody-dependent enhancement can be inhibited, severe symptoms of Covid-19 can be circumvented and mTOR inhibitors can be of use in the same (Zheng et al., 2020). Furthermore, recently a clinical trial to study the efficacy and safety of sirolimus as an adjuvant agent to the standard treatment protocol against COVID-19 infection is started (https: / / clinicaltrials.gov /ct2/show/NCT04461340 accessed on $15^{\text {th }}$ September, 2020 at $3.30 \mathrm{pm})$.

\subsection{Molecular docking against RdRp of SARS-Cov-2}

For the identification of phytoconstituents effective at RdRp, docking studies were performed using the Glide module of the
Schrodinger-9.6 software on the RdRp (PDB id: 7bv2). We have used nucleoside substrates uridine triphosphate (UTP), and thymidine triphosphate (TTP) as controls. UTP being the natural substrate for RdRp, interacted with RDRp at 5 amino acid residues, namely Lys551, Arg553, Arg555, Lys621 and Asp760 with a docking score - $6.7 \mathrm{kcal} / \mathrm{mol}$. Whereas TTP interacts with RdRp only with Arg 553 and Cys622.

Remdesivir is a prodrug that is hydrolyzed to yield the active metabolite. The molecular docking of remdesvir metabolite triphosphate (RemTP) into the active site of the RdRp enzyme reveals that it occupies the same binding pocket with root mean square deviation (RMSD) of $0.44^{\circ} \mathrm{A}$ which further validates the present docking protocol. RemTP interacted with Ser549, Lys551, Arg555 of RdRp with docking score of $-6.7 \mathrm{kcal} / \mathrm{mol}$. These binding residues overlaps with binding residues reported previously (Gao et al., 2020b; Zhang et al., 2020). We observed phytoconstituents to have better docking at the RdRp than remdesivir (Table 3). For example, hesperidin (docking score -10.01) bound tightly in the active site of RdRp. Hesperidin well occupied in the receptor cavity and makes hydrogen bonding with Arg555, ILE548, Asp845, and Lys545 (Fig. 8 and 9). The phytoconstituents provide promising lead compounds for designing novel RdRp inhibitors.

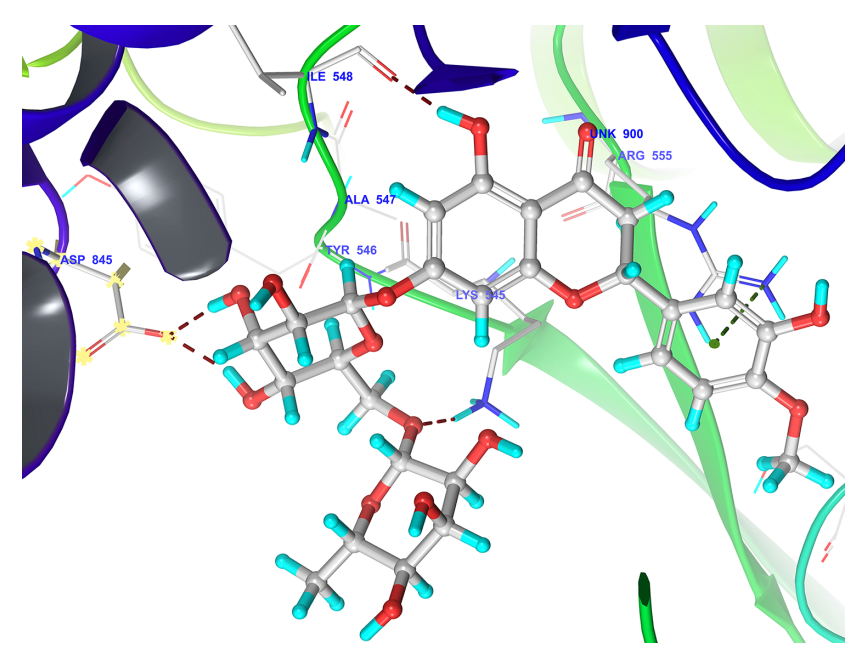

Fig. 8. 3D docking pose of hesperidin in to the RdRp receptor catalytic domain (Pdbid-7bv2) showing binding interaction with key amino acid residue of backbone protein. The backbone amino acid residues highlighted with grey colour while hesperidin highlighted by grey colour, Binding interaction (hydrogen bonding) depicted with red dashed lines. Ionic interaction was denoted by green dashed lines.

\section{Viral open reading frame $8(\mathrm{ORF})$ : Targeting the effector system}

Open reading frame $8(\mathrm{ORF} 8)$ is one of the accessory proteins present in beta coronaviruses, including SARS-CoV-2. All animal SARS-CoVs and human SARS-CoVs affected by early diseases contain full-length ORF8 (Song et al., 2005). However, in the mid and lately affected patients, there is a deletion of 29-nucleotide, resulting in the splitting of full-length ORF8 into putative ORF8a and ORF8b (Oostra et al., 2007). In SARS-CoV-2, the ORF8 protein does not contain a known region or motif and shares the least 

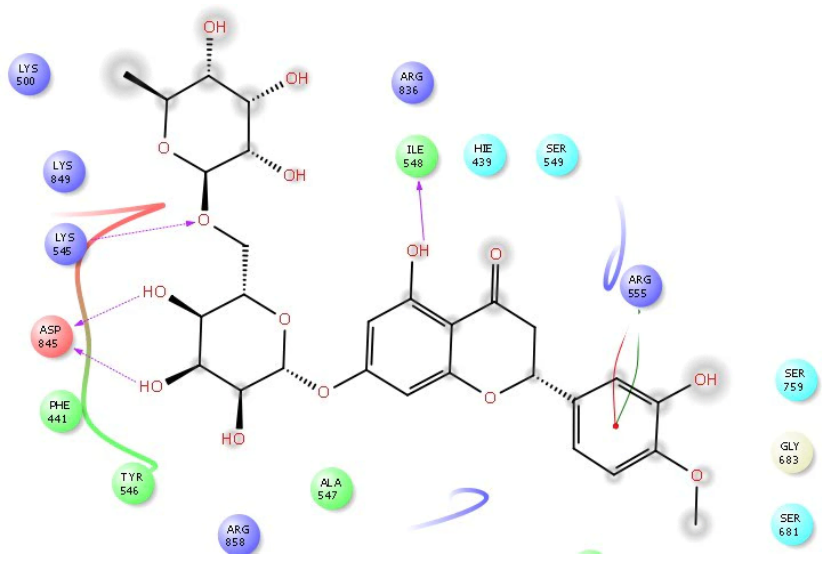

Fig. 9. 2D Ligplot interaction of hesperidin docked in to the RdRp receptor catalytic domain (Pdbid-7bv2). The pose was in 2D form and all the interactions were depicted by violet solid lines, hydrophobic amino acid residue denoted by green colour, positive charge residue denoted by blue colour, charged negative residue denoted by red colour, polar residue were denoted by sky blue colour.

homology with ORF8 of SARS-CoV. The viral protein encoded from ORF8 interacts with MHC-I and downregulates their surface expression, a function that is absent with ORF8a and ORF8b of SARS-CoV. Thus, ORF8 of SARS-CoV-2 seems more lethal as it also disrupts antigen presentation and reduction of recognition and elimination of viruses infected cells by cytotoxic $\mathrm{T}$ lymphocytes. Hence, in this review, we wish to throw some light concerning potential agents that can inhibit ORF8.

The sequencing of SARS-CoV-2 RNA revealed the coding sequences for structural and nonstructural proteins. Structural and molecular docking studies reported that the nonstructural protein encoded from open reading frame 8 (ORF8) of SARS-CoV-2 could combine with porphyrin to form a complex, facilitating the dissociation of the iron form heme (Liu and $\mathrm{Li}, 2020$ ), resulting in reduced oxygen-carrying capacity. ORF8 also interacts with MHC-I molecules directly and significantly downregulates the expression of MHC-1 on various cell types. MHC-I molecules selectively target ORF8 expressing cells for lysosomal degradation. Downregulation of MHC-1 reduces the recognition and the elimination of virus-infected cells by CTLs (Zhang et al., 2020). Therefore, the inhibition of ORF8 may enhance immune surveillance and accelerate the removal of SARS-CoV-2 infected cells and enhance the oxygen-carrying capacity of the blood. Currently, there is no approved drug for specific drug targeting of ORF8, and our findings with phytoconstituents may stimulate research efforts on the ORF8 target protein.

\subsection{Molecular docking against ORF8}

Molecular docking studies were performed against ORF8 using structural protein with PDB ID: 2AJF and 6BB5 (Table 3). Docking results reveal that the compounds luteolin- $O$-glucoside and hesperidin bound tightly to an active site of ORF8. The compounds luteolin- $O$-glucoside and hesperidin interacts with Tyr42, Phe43, His58, Lys61, His87 and Asn97. These compounds showed docking scores of -13.06 and $-14.45 \mathrm{kcal} / \mathrm{mol}$, respectively, against ORF8 (Fig. 10 and 11), and provide insights into developing ORF8 inhibitors.

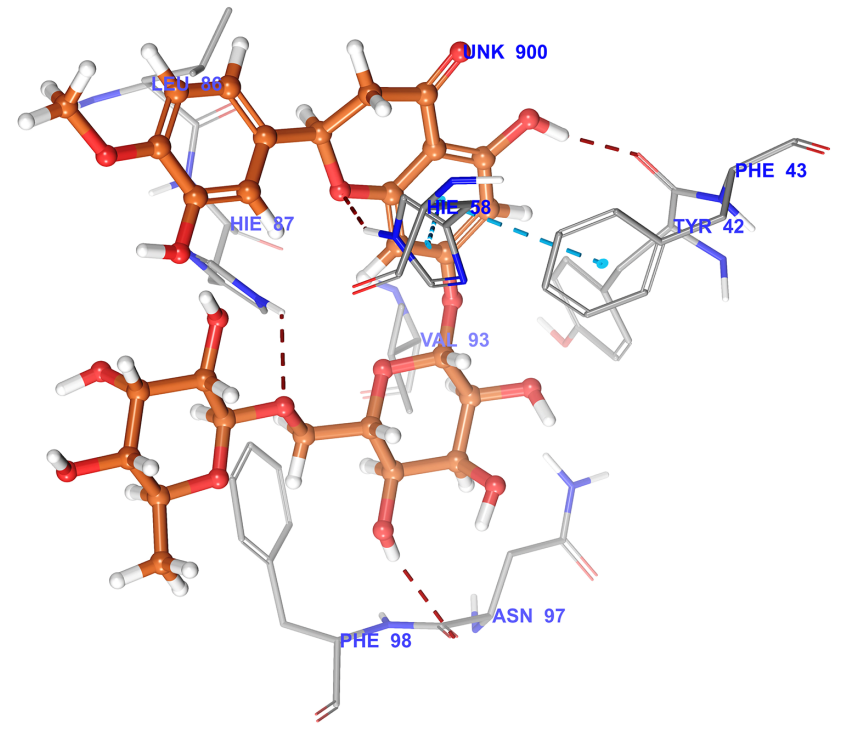

Fig. 10. 3D docking pose of hesperidin in to the ORF8 receptor catalytic domain (Pdbid-6bb5) showing binding interaction with key amino acid residue of backbone protein. The backbone amino acid residues highlighted with grey colour while hesperidin highlighted by brown colour Binding interaction (hydrogen bonding) depicted with red dashed lines. pipi interaction was denoted by blue dashed lines.

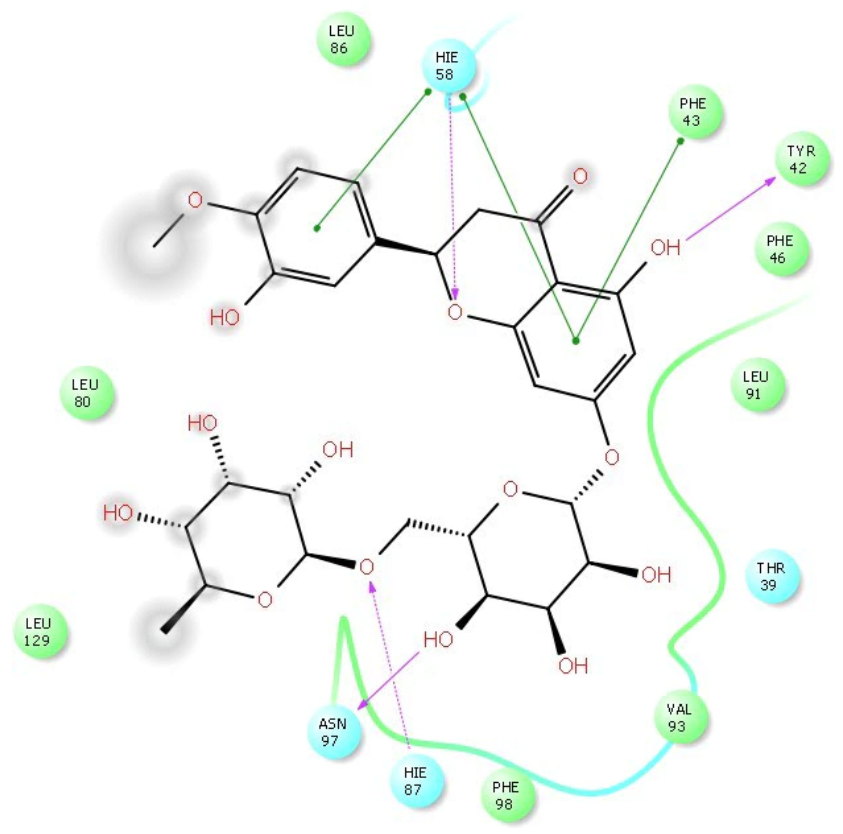

Fig. 11. 2D Ligplot interaction of hesperidin docked in to the ORF8 receptor catalytic domain (Pdbid-6bb5). The pose was in $2 \mathrm{D}$ form and all the interactions were depicted by violet solid lines, hydrophobic amino acid residue denoted by green colour, positive charge residue denoted by blue colour, charged negative residue denoted by red colour, polar residue were denoted by sky blue colour.

Although the efficacy of phytoconstituents and herbal plants in reducing the SARS-CoV-2 severity is under investigation, a systematic meta-analysis of Chinese Herbal Medicines suggests that herbal medicines may improve clinical outcomes when used 
in conjunction with conventional medical care (Fan et al., 2020). Moreover, a single case study reported a combination of herbal medicines comprising of several herbal plants enabled the patient to recover from COVID-19 (Girija and Sivan, 2020). Herbal medicines may be useful for the prevention, treatment of mildly symptomatic, severe, and recovering COVID-19 patients (Lee et al., 2020). Moreover, over eighty clinical investigations involving herbal medicines (ctri.nic.in; (www.clincialtrials.gov)) are in the registry for investigating the clinical benefits of phytoconstituents, and results from these studies will provide confirmation of clinical efficacy of phytoconstituents in treating COVID-19.

\section{Limitations of docking studies}

Naturally occurring phytochemicals are a powerful resource of chemical compounds to discover therapeutics for COVID-19 treatment. Molecular docking studies provided in this review and elsewhere offer insights into the interaction of phytoconstituents with the host or viral proteins. However, the studies on the functional implications of the molecular interactions on the target proteins in vitro and in vivo would shed light on the ability of these compounds to activate or inhibit their target proteins. Furthermore, insights into the potency, selectivity, mode of action, and therapeutic index for each phytochemical are required for testing in clinical trials. Nonetheless, these molecular docking studies provide insights for developing phytochemical-based therapeutics or designing new chemical entities (NCEs) suitable for generating safe and efficacious therapeutics from phytochemicals.

\section{Conclusions}

The pathogenesis and prognosis of COVID-19 are complex, involving inflammatory damage to multiple organs, including lung, heart, kidney, and vasculature. Besides serving as a cell entry site for SARS-CoV-2, ACE2 plays a very critical role in regulating the balance between the ACE2 driven anti-inflammatory actions and ACE/angiotensin AT1 receptors driven proinflammatory effects. Currently, there are no approved ACE2 inhibitors for preventing the entry of SARS-CoV-2 into host cells. Docking studies revealed phytoconstituents that interact with ACE2. Although the functional implications of these phytoconstituents on ACE2 activity are yet to be confirmed, available evidence suggests that inhibition of ACE2 may be a pivotal step to inhibit SARS-CoV-2 virus infection and consequent inflammatory damage. Phytoconstituents may interact with catalytic and/or S-protein binding sites. Further investigation of effect of phytoconstituents on the ACE2 catalytic and viral entry into cells using cell-based functional assays may provide insights into phytoconstituents. Furthermore, interaction of phytoconstituents at ACE2, AT1, and AT2 receptors suggests that the phytoconstituents may suppress the imbalance between ACE's counterregulatory functions by interacting with both arms of RAS. Phytoconstituents also may have inhibitory actions on SARSCoV-2 replication and improving the oxygen-carrying capacity of hemoglobin. Thus, phytoconstituents may have multiple sites of action, protecting and countering the inflammatory damage. Although the use of ACE inhibitors and AT1 receptor blockers during COVID-19 remains controversial, more recent clinical observations suggest that ACE inhibitors and AT1 blockers are not harmful in patients who had been taking the medications. Phytoconstituents may be useful both as prophylactic and treatment for COVID-19.
Moreover, COVID-19 patients who are severely affected and admitted to the hospital, particularly those treated in intensive care units, often have baseline comorbidities, including hypertension, diabetes, and obesity. These diseases are associated with strong activation of both the circulating and the local RAS, further complicating COVID-19 pathology. Although phytoconstituents may suppress both arms of RAS, severely ill COVID-19 patients may benefit from the diverse modulatory action of these phytoconstituents on the host RAS, viral RdRp and viral ORF8 targets.

\section{Authors' contributions}

Ramesh K. Goyal: Concept and skeleton of the Review Paper Jaseela Majeed: Target Identifications

Rajiv Tonk: Over view of repurposed drugs and their meachanisms

Mahaveer Dhobi: Herbal drugs and Phytoconstituents identification

Bhoomika Patel: Pharmacological and mechanism of action

Kalicharan Sharma: Docking studies with Rajiv Tonk and Jaseela Majeed

Subbu Apparsundaram: Clinical aspects and correlation from new drug discovery point of view

\section{Acknowledgments}

Authors acknowledge Nirma University, Ahmedabad and Mankind Research Center, Gurgaon, Haryanam India for their cooperation.

\section{Conflicts of Interest}

Authors declare that there is no conflict of interest regarding the publication of this article.

Submitted: June 20, 2020

Revised: September 21, 2020

Accepted: September 23, 2020

Published: September 30, 2020

\section{References}

Abdelli, I., Hassani, F., Brikci, B S. and Ghalem, S. (2020) In silico study the inhibition of angiotensin converting enzyme 2 receptor of COVID19 by Ammoides verticillata components harvested from Western Algeria. Journal of Biomolecular Structure and Dynamics 4, 1-14.

Acanfora, D., Ciccone, M. M., Scicchitano, P., Acanfora, C. and Casucci, G. (2020) Neprilysin inhibitor-angiotensin II receptor blocker combination (Sacubitril/Valsartan): Rationale for adoption in SARS-CoV-2 patients. European Heart Journal - Cardiovascular Pharmacotherapy 6, 135-136.

Amin, M. and Abbas, G. (2020) Docking study of chloroquine and hydroxychloroquine interaction with SARS-CoV-2 spike glycoprotein an in silico insight into the comparative efficacy of repurposing antiviral drugs. Journal of Biomolecular Structure and Dynamics 6, 1-13.

Antinori, S., Cossu, M. V., Ridolfo, A. L., Rech, R., Bonazzetti, C., Pagani, G., Gubertini, G., Coen, M., Magni, C., Castelli, A., Borghi, B., Colombo, R., Giorgi, R., Angeli, E., Mileto, D., Milazzo, L., Vimercati, S., Pellicciotta, M., Corbellino, M., Torre, A., Rusconi, S., Oreni, L., Gismondo, M. R., Giacomelli, A., Meroni, L., Rizzardini, G. and Galli, M. (2020) Compassionate remdesivir treatment of severe Covid19 pneumonia in intensive care unit (ICU) and Non-ICU patients: Clinical outcome and differences in post-treatment hospitalisation status. Pharmacological Research 158, 104899.

Arthur, J. S. C. and Ley, S. C. (2013) Mitogen-activated protein kinases in innate immunity. Nature Reviews. Immunology 13, 679-692. 
Ashburn, T. T. and Thor, K. B. (2004) Drug repositioning: identifying and developing new uses for existing drugs. Nature Reviews Drug Discovery 3, 673-683.

Babadaei, M. M. N., Hasan, A., Bloukh, S. H., Edis, Z., Sharifi, M., Kachooei, E. and Falahati, M. (2020) The expression level of angiotensinconverting enzyme 2 determines the severity of COVID-19: Lung and heart tissue as targets. Journal of Biomolecular Structure and Dynamics 7, 1-7.

Badawi, A. and Ryoo, S. G. (2016) Prevalence of comorbidities in the Middle East Respiratory Syndrome Coronavirus (MERS-CoV): a systematic review and meta-analysis. International Journal of Infectious Diseases 49, 129-133.

Beck, B. R., Shin, B., Choi, Y., Park, S. and Kang, K. (2020) Predicting commercially available antiviral drugs that may act on the novel coronavirus (SARS-CoV-2) through a drug-target interaction deep learning model. Computational and Structural Biotechnology Journal 18, 784790.

Beigel, J. H., Tomashek, K. M., Dodd, L. E., Mehta, A. K., Zingman, B. S., Kalil, A. C., Hohmann, E., Chu, H. Y., Luetkemeyer, A., Kline, S., Lopez de Castilla, D., Finberg, R. W., Dierberg, K., Tapson, V., Hsieh, L., Patterson, T. F., Paredes, R., Sweeney, D. A., Short, W. R., Touloumi, G., Lye, D. C., Ohmagari, N., Oh, M. D., Ruiz-Palacios, G. M., Benfield, T., Fätkenheuer, G., Kortepeter, M. G., Atmar, R. L., Creech, C. B., Lundgren, J., Babiker, A. G., Pett, S., Neaton, J. D., Burgess, T. H., Bonnett, T., Green, M., Makowski, M., Osinusi, A., Nayak, S. and Lane, H. C. (2020) Remdesivir for the Treatment of Covid-19 - preliminary report. New England Journal of Medicine 22, NEJMoa2007764.

Benarba, B. and Pandiella, A. (2020) Medicinal plants as sources of active molecules against COVID-19. Frontiers in Pharmacology 11, 1189.

Benetti, E., Tita, R., Spiga, O., Ciolfi, A., Birolo, G., Bruselles, A., Doddato, G., Giliberti, A., Marconi, C., Musacchia, F., Pippucci, T., Torella, A., Trezza, A., Valentino, F., Baldassarri, M., Brusco, A., Asselta, R., Bruttini, M., Furini, S., Seri, M., Nigro, V., Matullo, G., Tartaglia, M., Mari, F., Study, G.-C. M., Renieri, A. and Pinto, A. M. (2020) ACE2 gene variants may underlie interindividual variability and susceptibility to COVID-19 in the Italian population. European Journal of Human Genetics 17, 1-13.

Bilinska, K., Jakubowska, P., Von Bartheld, C. S. and Butowt, R. (2020) Expression of the SARS-CoV-2 entry proteins, ACE2 and TMPRSS2, in cells of the olfactory epithelium: Identification of cell types and trends with age. ACS Chemical Neuroscience 11, 1555-1562.

Birnbaum, R. A. (2020) Renin-angiotensin-aldosterone system inhibitors in COVID-19. New England Journal of Medicine 382, e92.

Boukhatem, M. N. and Setzer, W. N. (2020) Aromatic herbs, medicinal plant-derived essential oils, and phytochemical extracts as potential therapies for Coronaviruses: Future perspectives. Plants 9, 800.

Bourgonje, A. R., Abdulle, A. E., Timens, W., Hillebrands, J. L., Navis, G. J., Gordijn, S. J., Bolling, M. C., Dijkstra, G., Voors, A. A., Osterhaus, A. D., Van der Voort, P. H., Mulder, D. J. and Van Goor, H. (2020) Angiotensin-converting enzyme 2 (ACE2), SARS-CoV-2 and the pathophysiology of coronavirus disease 2019 (COVID-19). Journal of Pathology 251, 228-248.

Cai, Q., Yang, M., Liu, D., Chen, J., Shu, D., Xia, J., Liao, X., Gu, Y., Cai, Q., Yang, Y., Shen, C., Li, X., Peng, L., Huang, D., Zhang, J., Zhang, S., Wang, F., Liu, J., Chen, L., Chen, S., Wang, Z., Zhang, Z., Cao, R., Zhong, W., Liu, Y. and Liu, L. (2020) Experimental treatment with favipiravir for COVID-19: An open-label control study. Engineering (in press).

Cannata, F., Chiarito, M., Reimers, B., Azzolini, E., Ferrante, G., My, I., Department of Biomedical Sciences, Humanitas University, Pieve Emanuele-Milan, Italy, Viggiani, G., Panico, C., Regazzoli, D., Ciccarelli, M., Voza, A., Aghemo, A., Li, H., Wang, Y., Condorelli, G., and Stefanini, G. G. (2020) Continuation versus discontinuation of ACE inhibitors or angiotensin II receptor blockers in COVID-19: effects on blood pressure control and mortality. European Heart Journal - Cardiovascular Pharmacotherapy (in press).

Cao, B., Wang, Y., Wen, D., Liu, W., Wang, J., Fan, G., Ruan, L., Song, B., Cai, Y., Wei, M., Li, X., Xia, J., Chen, N., Xiang, J., Yu, T., Bai, T., Xie, X., Zhang, L., Li, C., Yuan, Y., Chen, H., Li, H., Huang, H., Tu, S.,
Gong, F., Liu, Y., Wei, Y., Dong, C., Zhou, F., Gu, X., Xu, J., Liu, Z., Zhang, Y., Li, H., Shang, L., Wang, K., Li, K., Zhou, X., Dong, X., Qu, Z., Lu, S., Hu, X., Ruan, S., Luo, S., Wu, J., Peng, L., Cheng, F., Pan, L., Zou, J., Jia, C., Wang, J., Liu, X., Wang, S., Wu, X., Ge, Q., He, J., Zhan, H., Qiu, F., Guo, L., Huang, C., Jaki, T., Hayden, F. G., Horby, P. W., Zhang, D. and Wang, C. (2020) A trial of lopinavir-ritonavir in adults hospitalized with Severe Covid-19. New England Journal of Medicine 382, 1787-1799.

Capone, C. A., Subramony, A., Sweberg, T., Schneider, J., Shah, S., Rubin, L., Schleien, C., Epstein, S., Johnson, J. C., Kessel, A., Misra, N., Mitchell, E., Palumbo, N., Rajan, S., Rocker, J., Williamson, K. and Davidson, K. W. (2020) Characteristics, cardiac involvement, and outcomes of multisystem inflammatory syndrome of childhood associated with Severe Acute Respiratory Syndrome Coronavirus 2 Infection. the Journal of Pediatrics 224, 141-145.

Cavalli, E., Bramanti, A., Ciurleo, R., Tchorbanov, A., Giordano, A., Fagone, P., Belizna, C., Bramanti, P., Shoenfeld, Y. and Nicoletti, F. (2020) Entangling COVID-19 associated thrombosis into a secondary antiphospholipid antibody syndrome: Diagnostic and therapeutic perspectives (Review). International Journal of Molecular Medicine 46, 903-912.

Chang, R. and Sun, W. (2020) Repositioning chloroquine as antiviral prophylaxis against COVID-19: potential and challenges. Drug Discovery Today

Chen, C. C., Chow, M. P., Huang, W. C., Lin, Y. C. and Chang, Y. J. (2004) Flavonoids inhibit tumor necrosis factor-alpha-induced up-regulation of intercellular adhesion molecule-1 (ICAM-1) in respiratory epithelial cells through activator protein-1 and nuclear factor-kappa b: structureactivity relationships. Molecular Pharmacology 66, 683-693.

Chen, L., Li, X., Chen, M., Feng, Y. and Xiong, C. (2020) The ACE2 expression in human heart indicates new potential mechanism of heart injury among patients infected with SARS-CoV-2. Cardiovascular Research 116, 1097-1100.

Cinatl, J., Morgenstern, B., Bauer, G., Chandra, P., Rabenau, H. and Doerr, H. (2003) Glycyrrhizin, an active component of liquorice roots, and replication of SARS-associated coronavirus. The Lancet 361, 20452046.

Chandrasekar, V. T., Venkatesalu, B., Patel, H. K., Spadaccini, M., Manteuffel, J. and Ramesh, M. (2020) Systematic review and meta-analysis of effectiveness of treatment options against SARS-CoV-2 Infection. Journal of Medical Virology (in press).

Corley, M. J. and Ndhlovu, L. C. (2020) DNA methylation analysis of the COVID-19 host cell receptor, angiotensin I converting enzyme 2 Gene (ACE2) in the respiratory system reveal age and gender differences. Europe PMC (in press).

Cortegiani, A., Ippolito, M., Ingoglia, G., Iozzo, P., Giarratano, A. and Einav, S. (2020) Update I. A systematic review on the efficacy and safety of chloroquine/hydroxychloroquine for COVID-19. Journal of Critical Care 59, 176-190.

Crisafulli, S., Isgrò, V., La Corte, L., Atzeni, F. and Trifirò, G. (2020) Potential role of anti-interleukin (IL)-6 drugs in the treatment of COVID19: Rationale, clinical evidence and risks. Biodrugs 34, 415-422.

Crowley, S. D. and Rudemiller, N. P. (2017) Immunologic effects of the renin-angiotensin system. Journal of the American Society of Nephrology 28, 1350-1361.

Dales, N. A., Gould, A. E., Brown, J. A., Calderwood, E. F., Guan, B., Minor, C. A., Gavin, J. M., Hales, P., Kaushik, V. K., Stewart, M., Tummino, P. J., Vickers, C. S., Ocain, T. D. and Patane, M. A. (2002) Substrate-based design of the first class of angiotensinconverting enzyme-related carboxypeptidase (ACE2) Inhibitors. Journal of the American Chemical Society 124, 11852-11853.

Danser, A. H. J., Epstein, M. and Batlle, D. (2020) Renin-angiotensin system blockers and the COVID-19 pandemic. Hypertension 75, 13821385.

Davoudi-Monfared, E., Rahmani, H., Khalili, H., Hajiabdolbaghi, M., Salehi, M., Abbasian, L., Kazemzadeh, H. and Yekaninejad, M. S. (2020) A randomized clinical trial of the efficacy and safety of interferon beta-1a in treatment of severe COVID-19. Antimicrobial Agents and Chemotherapy 64, 1-14.

de Maat, S., de Mast, Q., Danser, A. H. J., van de Veerdonk, F. L. and Maas, 
C. (2020) Impaired breakdown of bradykinin and its metabolites as a possible cause for pulmonary edema in COVID-19 infection. Seminars in Thrombosis and Hemostasis

de Simone, G. and Mancusi, C. (2020) COVID-19: Timing is important. European Journal of Internal Medicine 77, 134-135.

Dehelean, C. A., Lazureanu, V., Coricovac, D., Mioc, M., Oancea, R., Marcovici, I., Pinzaru, I., Soica, C., Tsatsakis, A. M. and Cretu, O. (2020) SARS-CoV-2: Repurposed Drugs and Novel Therapeutic ApproachesInsights into Chemical Structure-Biological Activity and toxicological screening. Journal of Clinical Medicine 9, 2084.

Del Valle, D. M., Kim-Schulze, S., Hsin-Hui, H., Beckmann, N. D., Nirenberg, S., Wang, B., Lavin, Y., Swartz, T., Madduri, D., Stock, A., Marron, T., Xie, H., Patel, M. K., van Oekelen, O., Rahman, A., Kovatch, P., Aberg, J., Schadt, E., Jagannath, S., Mazumdar, M., Charney, A., Firpo-Betancourt, A., Mendu, D. R., Jhang, J., Reich, D., Sigel, K., Cordon-Cardo, C., Feldmann, M., Parekh, S., Merad, M. and Gnjatic, S. (2020) An inflammatory cytokine signature helps predict COVID-19 severity and death. medRxiv (in press).

Ding, X., Zhu, F., Yang, Y. and Li, M. (2013) Purification, antitumor activity in vitro of steroidal glycoalkaloids from black nightshade (Solanum nigrum L.). Food Chemistry 141, 1181-1186.

Dyall, J., Coleman, C. M., Hart, B. J., Venkataraman, T., Holbrook, M. R., Kindrachuk, J., Johnson, R. F., Olinger, G. G., Jahrling, P. B., Laidlaw, M., Johansen, L. M., Lear-Rooney, C. M., Glass, P. J., Hensley, L. E. and Frieman, M. B. (2014) Repurposing of clinically developed drugs for treatment of middle east respiratory syndrome coronavirus infection. Antimicrobial Agents and Chemotherapy 58, 4885-4893.

Ekins, S., Mottin, M., Ramos, P., Sousa, B. K. P., Neves, B. J., Foil, D. H., Zorn, K. M., Braga, R. C., Coffee, M., Southan, C., Puhl, A. C. and Andrade, C. H. (2020) Deja Vu: stimulating open drug discovery for SARS-CoV-2. Drug Discovery Today 25, 928-941.

Ettman, C. K., Brown University School of Public Health, Providence, Rhode Island, Abdalla, S. M., Cohen, G. H., Columbia Mailman School of Public Health, New York, New York, Sampson, L., Vivier, P. M., Hassenfeld Child Health Innovation Institute, Providence, Rhode Island and Galea, S. (2020) Prevalence of depression symptoms in US adults before and during the COVID-19 pandemic. JAMA Network Open 3, e2019686.

Fagone, P., Ciurleo, R., Lombardo, S. D., Iacobello, C., Palermo, C. I., Shoenfeld, Y., Bendtzen, K., Bramanti, P. and Nicoletti, F. (2020) Transcriptional landscape of SARS-CoV-2 infection dismantles pathogenic pathways activated by the virus, proposes unique sex-specific differences and predicts tailored therapeutic strategies. Autoimmunity Reviews 19, 102571 .

Fan, A. Y., Gu, S. and Alemi, S. F. (2020) Chinese herbal medicine for COVID-19: Current evidence with systematic review and metaanalysis. Journal of Integrative Medicine 18, 385-394.

Ferner, R. E. and Aronson, J. K. (2020) Chloroquine and hydroxychloroquine in covid-19. BMJ 1, m1432.

Crisafulli, S., Isgrò, V., La Corte, L., Atzeni, F. and Trifirò, G. (2020) Potential role of anti-interleukin (IL)-6 drugs in the treatment of COVID19: Rationale,clinical evidence and risks. Biodrugs 34, 415-422.

Ferrario, C. M., Ahmad, S. and Groban, L. (2020) Mechanisms by which angiotensin-receptor blockers increase ACE2 levels. Nature Reviews Cardiology 17, 378-378.

Fosbøl, E. L., Butt, J. H., Østergaard, L., Andersson, C., Selmer, C., Kragholm, K., Schou, M., Phelps, M., Gislason, G. H., Department of Cardiovascular Epidemiology and Research, The Danish Heart Foundation, Copenhagen, Denmark, Gerds, T. A., Torp-Pedersen, C. and Køber, L. (2020) Association of angiotensin-converting enzyme inhibitor or angiotensin receptor blocker use with COVID-19 diagnosis and mortality. JAMA 324, 168

Gao, L., Xu, J. and Chen, S. (2020a) In Silico screening of potential chinese herbal medicine against COVID-19 by targeting SARS-CoV-2 3CLpro and angiotensin converting enzyme II using molecular docking. Chinese Journal of Integrative Medicine 26, 527-532.

Gao, Y., Yan, L., Huang, Y., Liu, F., Zhao, Y., Cao, L., Wang, T., Sun, Q., Ming, Z., Zhang, L., Ge, J., Zheng, L., Zhang, Y., Wang, H., Zhu, Y., Zhu, C., Hu, T., Hua, T., Zhang, B., Yang, X., Li, J., Yang, H., Liu, Z., Xu, W., Guddat, L. W., Wang, Q., Lou, Z. and Rao, Z. (2020b) Struc- ture of the RNA-dependent RNA polymerase from COVID-19 virus. Science 368, 779-782.

Gheblawi, M., Wang, K., Viveiros, A., Nguyen, Q., Zhong, J., Turner, A. J., Raizada, M. K., Grant, M. B. and Oudit, G. Y. (2020) Angiotensinconverting enzyme 2: SARS-CoV-2 receptor and regulator of the reninangiotensin system. Circulation Research 126, 1456-1474.

Ghisalberti, E. L. (2000) Lantana camara L. (Verbenaceae). Fitoterapia 71, 467-486.

Gilbert, J., Henske, P., Singh, A. (2003) Rebuilding big pharma's business model, in vivo. The Business \& Medicine Report 21,73-80.

Girija, P. L. T. and Sivan, N. (2020) Ayurvedic treatment of COVID19/SARS-CoV-2: A case report. Journal of Ayurveda and Integrative Medicine (in press).

Gorbalenya, A. E., Baker, S. C., Baric, R. S., Groot, de R. J., Drosten, C., Gulyaeva, A. A., Haagmans, B. L., Lauber, C., Leontovich, A. M., Neuman, B. W., Penzar, D., Perlman, S., Poon, L. L. M., Samborskiy, D., Sidorov, I. A., Sola, I., Ziebuhr, J. (2020) Severe acute respiratory syndrome-related coronavirus: The species and its viruses - a statement of the coronavirus study group. (in press).

Grein, J., Ohmagari, N., Shin, D., Diaz, G., Asperges, E., Castagna, A., Feldt, T., Green, G., Green, M. L., Lescure, F., X., Nicastri, E., Oda, R., Yo, K., Quiros-Roldan, E., Studemeister, A., Redinski, J., Ahmed, S., Bernett, J., Chelliah, D., Chen, D., Chihara, S., Cohen, S. H., Cunningham, J., D'Arminio Monforte, A., Ismail, S., Kato, H., Lapadula, G., L'Her, E., Maeno, T., Majumder, S., Massari, M., Mora-Rillo, M., Mutoh, Y., Nguyen, D., Verweij, E., Zoufaly, A., Osinusi, A. O., DeZure, A., Zhao, Y., Zhong, L., Chokkalingam, A., Elboudwarej, E., Telep, L., Timbs, L., Henne, I., Sellers, S., Cao, H., Tan, S. K., Winterbourne, L., Desai, P., Mera, R., Gaggar, A., Myers, R. P., Brainard, D. M., Childs, R. and Flanigan, T. (2020) Compassionate use of remdesivir for patients with severe Covid-19. New England Journal of Medicine 382, 2327-2336.

Gross, L. Z. F., Sacerdoti, M., Piiper, A., Zeuzem, S., Leroux, A. E. and Biondi, R. M. (2020) ACE2, the Receptor that Enables Infection by SARS-CoV-2: Biochemistry, Structure, Allostery and Evaluation of the Potential Development of ACE2 Modulators. Chemmedchem 15, 16821690.

Gu, X.Y., Shen, X.F., Wang, L., Wu, Z.W., Li, F., Chen, B., Zhang, G.L. and Wang, M.K. (2018) Bioactive steroidal alkaloids from the fruits of Solanum nigrum. Phytochemistry 147, 125-131.

Guerrero, L., Castillo, J., Quiñones, M., Garcia-Vallvé, S., Arola, L., Pujadas, G. and Muguerza, B. (2012) Inhibition of angiotensin-converting enzyme activity by flavonoids: structure-activity relationship studies. Plos One 7, e49493.

Gupta, A., Madhavan, M. V., Sehgal, K., Nair, N., Mahajan, S., Sehrawat, T. S., Bikdeli, B., Ahluwalia, N., Ausiello, J. C., Wan, E. Y., Freedberg, D. E., Kirtane, A. J., Parikh, S. A., Maurer, M. S., Nordvig, A. S., Accili, D., Bathon, J. M., Mohan, S., Bauer, K. A., Leon, M. B., Krumholz, H. M., Uriel, N., Mehra, M. R., Elkind, M. S. V., Stone, G. W., Schwartz, A., Ho, D. D., Bilezikian, J. P. and Landry, D. W. (2020) Extrapulmonary manifestations of COVID-19. Nature Medicine 26, 1017-1032.

Gyebi, G. A., Ogunro, O. B., Adegunloye, A. P., Ogunyemi, O. M. and Afolabi, S. O. (2020) Potential inhibitors of coronavirus 3chymotrypsin-like protease (3CLpro): an in silico screening of alkaloids and terpenoids from African medicinal plants. Journal of Biomolecular Structure and Dynamics 12, 1-13.

Haggag, Y. A., El-Ashmawy, N. E. and Okasha, K. M. (2020) Is hesperidin essential for prophylaxis and treatment of COVID-19 Infection? Medical Hypotheses 144, 109957.

Hamming, I., Timens, W., Bulthuis, M., Lely, A., Navis, G. and van Goor, H. (2004) Tissue distribution of ACE2 protein, the functional receptor for SARS coronavirus. A first step in understanding SARS pathogenesis. The Journal of Pathology 203, 631-637.

Heredia, A., Le, N., Gartenhaus, R. B., Sausville, E., Medina-Moreno, S., Zapata, J. C., Davis, C., Gallo, R. C. and Redfield, R. R. (2015) Targeting of mTOR catalytic site inhibits multiple steps of the HIV-1 lifecycle and suppresses HIV-1 viremia in humanized mice. Proceedings of the National Academy of Sciences 112, 9412-9417.

Herbert, J. M., Maffrand, J. P., Taoubi, K., Augereau, J. M., Fouraste, I. 
and Gleye, J. (1991) Verbascoside isolated from Lantana camara, an inhibitor of protein kinase C. Journal of Natural Products 54, 1595 1600 .

Hilgenfeld, R. and Peiris, M. (2013) From SARS to MERS: 10 years of research on highly pathogenic human coronaviruses. Antiviral Research 100, 286-295.

Ho, T., Wu, S., Chen, J., Li, C. and Hsiang, C. (2007) Emodin blocks the SARS coronavirus spike protein and angiotensin-converting enzyme 2 interaction. Antiviral Research 74, 92-101.

Hoffmann, M., Schroeder, S., Kleine-Weber, H., Müller, M. A., Drosten, C. and Pöhlmann, S. (2020) Nafamostat mesylate blocks activation of SARS-CoV-2: new treatment option for COVID-19. Antimicrobial Agents and Chemotherapy 64

Horby, P., Lim, W. S., Emberson, J. R., Mafham, M., Bell, J. L., Linsell, L., Staplin, N., Brightling, C., Ustianowski, A., Elmahi, E., Prudon, B., Green, C., Felton, T., Chadwick, D., Rege, K., Fegan, C., Chappell, L. C., Faust, S. N., Jaki, T., Jeffery, K., Montgomery, A., Rowan, K., Juszczak, E., Baillie, J. K., Haynes, R. and Landray, M. J. (2020) Dexamethasone in hospitalized patients with COVID-19 - preliminary report. New England Journal of Medicine (in press).

Horie, S., McNicholas, B., Rezoagli, E., Pham, T., Curley, G., McAuley, D., O'Kane, C., Nichol, A., dos Santos, C., Rocco, P. R. M., Bellani, G. and Laffey, J. G. (2020) Emerging pharmacological therapies for ARDS: COVID-19 and beyond. Intensive Care Medicine 2, 1-19.

Huang, H., Syu, K. and Lin, J. (2010) Chemical composition of Solanum nigrum Linn extract and induction of autophagy by leaf water extract and its major flavonoids in AU565 breast cancer cells. Journal of Agricultural and Food Chemistry 58, 8699-8708.

Huang, F., Li, Y., Leung, E. L., Liu, X., Liu, K., Wang, Q., Lan, Y., Li, X., Yu, H., Cui, L., Luo, H. and Luo, L. (2020) A review of therapeutic agents and Chinese herbal medicines against SARS-COV-2 (COVID19). Pharmacological Research 158, 104929.

Ibrahim, M. A. A., Abdeljawaad, K. A. A., Abdelrahman, A. H. M. and Hegazy, M. F. (2020a) Natural-like products as potential SARS-CoV2 M(pro) inhibitors: In-silico drug discovery. Journal of Biomolecular Structure and Dynamics 91, 1-13.

Ibrahim, H., Perl, A., Smith, D., Lewis, T., Kon, Z., Goldenberg, R. Yarta, K., Staniloae, C. and Williams, M. (2020b) Therapeutic blockade of inflammation in severe COVID-19 infection with intravenous $\mathrm{N}$-acetylcysteine. Clinical Immunology 219, 108544

Inal, J. (2020) Decoy ACE2-expressing extracellular vesicles that competitively bind SARS-CoV-2 as a possible COVID-19 therapy. Clinical Science 134, 1301-1304.

Jacobs, M., Rodger, A., Bell, D. J., Bhagani, S., Cropley, I., Filipe, A., Gifford, R. J., Hopkins, S., Hughes, J., Jabeen, F., Johannessen, I., Karageorgopoulos, D., Lackenby, A., Lester, R., Liu, R. S., MacConnachie, A., Mahungu, T., Martin, D., Marshall, N., Mepham, S., Orton, R., Palmarini, M., Patel, M., Perry, C., Peters, S. E., Porter, D., Ritchie, D., Ritchie, N. D., Seaton, R. A., Sreenu, V. B., Templeton, K., Warren, S., Wilkie, G. S., Zambon, M., Gopal, R. and Thomson, E. C. (2016) Late Ebola virus relapse causing meningoencephalitis: a case report. Lancet 388, 498-503.

Jamaluddin, M., Meng, T., Sun, J., Boldogh, I., Han, Y. and Brasier, A. R. (2000) Angiotensin II induces nuclear factor (NF)-kappab1 isoforms to bind the angiotensinogen gene acute-phase response element: a stimulus-specific pathway for NF-kappab activation. Molecular Endocrinology (Baltimore, Md.) 14, 99-113.

Java, A., Apicelli, A. J., Liszewski, M. K., Coler-Reilly, A., Atkinson, J. P., Kim, A. H. J. and Kulkarni, H. S. (2020) The complement system in COVID-19: friend and foe? JCI Insight 5, e140711.

Jose, R. J. and Manuel, A. (2020) COVID-19 cytokine storm: the interplay between inflammation and coagulation. the Lancet Respiratory Medicine 8, e46-e47.

Jin, Z., Du, X., Xu, Y., Deng, Y., Liu, M., Zhao, Y., Zhang, B., Li, X., Zhang, L., Peng, C., Duan, Y., Yu, J., Wang, L., Yang, K., Liu, F., Jiang, R., Yang, X., You, T., Liu, X., Yang, X., Bai, F., Liu, H., Liu, X., Guddat, L. W., Xu, W., Xiao, G., Qin, C., Shi, Z., Jiang, H., Rao, Z. and Yang, H. (2020) Structure of M(Pro) from SARS-CoV-2 and discovery of its inhibitors. Nature 582, 289-293.

Joshi, T., Joshi, T., Sharma, P., Mathpal, S., Pundir, H., Bhatt, V. and Chan- dra, S. (2020) In silico screening of natural compounds against COVID19 by targeting Mpro and ACE2 using molecular docking. European Review for Medical and Pharmacological Sciences 24, 4529-4536.

Kandimalla, R., John, A., Abburi, C., Vallamkondu, J. and Reddy, P. H. (2020) Current status of multiple drug molecules, and vaccines: An update in SARS-CoV-2 therapeutics. Molecular Neurobiology 57, 41064116.

Kang, Y., Chen, T., Mui, D., Ferrari, V., Jagasia, D., Scherrer-Crosbie, M., Chen, Y. and Han, Y. (2020) Cardiovascular manifestations and treatment considerations in COVID-19. Heart 106, 1132-1141.

Kalra, R. S., Tomar, D., Meena, A. S. and Kandimalla, R. (2020) SARSCoV-2, ACE2, and hydroxychloroquine: cardiovascular complications, therapeutics, and clinical readouts in the current settings. Pathogens $\mathbf{9}$, 546.

Kiran, G., Karthik, L., Shree Devi, M. S., Sathiyarajeswaran, P., Kanakavalli, K., Kumar, K. M. and Ramesh Kumar, D. (2020) In Silico computational screening of Kabasura Kudineer - Official Siddha Formulation and JACOM against SARS-CoV-2 spike protein. Journal of Ayurveda and Integrative Medicine (in press).

Kumar, Y., Singh, H. and Patel, C. N. (2020) In silico prediction of potential inhibitors for the main protease of SARS-CoV-2 using molecular docking and dynamics simulation based drug-repurposing. Journal of Infection and Public Health 13, 1210-1223.

Kuba, K., Imai, Y. and Penninger, J. M. (2013) Multiple functions of angiotensin-converting enzyme 2 and its relevance in cardiovascular diseases. Circulation Journal 77, 301-308.

Kuno, T., Takahashi, M., Obata, R. and Maeda, T. (2020) Cardiovascular comorbidities, cardiac injury, and prognosis of COVID-19 in New York city. American Heart Journal 226, 24-25

Lee, B., Lee, J. A., Kim, K., Choi, J. and Jung, H. (2020) A consensus guideline of herbal medicine for coronavirus disease 2019. Integrative Medicine Research 9, 100470.

Li, W., Zhang, C., Sui, J., Kuhn, J. H., Moore, M. J., Luo, S., Wong, S., Huang, I., Xu, K., Vasilieva, N., Murakami, A., He, Y., Marasco, W. A., Guan, Y., Choe, H. and Farzan, M. (2005) Receptor and viral determinants of SARS-coronavirus adaptation to human ACE2. The EMBO Journal 24, 1634-1643.

Li, M., Li, L., Zhang, Y. and Wang, X. (2020a) Expression of the SARS$\mathrm{CoV}-2$ cell receptor gene ACE2 in a wide variety of human tissues. Infectious Diseases of Poverty 9, 45.

Li, B., Yang, J., Zhao, F., Zhi, L., Wang, X., Liu, L., Bi, Z. and Zhao, Y. (2020b) Prevalence and impact of cardiovascular metabolic diseases on COVID-19 in China. Clinical Research in Cardiology 109, 531-538.

Liu, W., and Li, H. (2020) COVID-19: Attacks the 1-Beta chain of hemoglobin and captures the porphyrin to inhibit human heme metabolism. ChemRxiv (in press).

Lo, M. K., Jordan, R., Arvey, A., Sudhamsu, J., Shrivastava-Ranjan, P., Hotard, A. L., Flint, M., McMullan, L. K., Siegel, D., Clarke, M. O., Mackman, R. L., Hui, H. C., Perron, M., Ray, A. S., Cihlar, T., Nichol, S. T. and Spiropoulou, C. F. (2017) GS-5734 and its parent nucleoside analog inhibit Filo-, Pneumo-, and Paramyxoviruses. Scientific Reports 7, 43395 .

Lopes, R. D., Macedo, A. V. S., de Barros E. S. P. G. M., Moll-Bernardes, R. J., Feldman, A., D'Andréa Saba Arruda, G., de Souza, A. S., de Albuquerque, D. C., Mazza, L., Santos, M. F., Salvador, N. Z., Gibson, C. M., Granger, C. B., Alexander, J. H. and de Souza, O. F. (2020) Continuing versus suspending angiotensin-converting enzyme inhibitors and angiotensin receptor blockers: Impact on adverse outcomes in hospitalized patients with severe acute respiratory syndrome coronavirus 2 (SARS-CoV-2)--the brace corona trial. American Heart Journal 226, 49-59.

Mackey, K., King, V. J., Gurley, S., Kiefer, M., Liederbauer, E., Vela, K., Sonnen, P. and Kansagara, D. (2020) Risks and impact of angiotensin-converting enzyme inhibitors or angiotensin-receptor blockers on SARS-CoV-2 infection in adults: A living systematic review. Annals of Internal Medicine 173, 195-203.

Mahase, E. (2020) Covid-19: Low dose steroid cuts death in ventilated patients by one third, trial finds. BMJ 369, m2422.

Mahmudpour, M., Roozbeh, J., Keshavarz, M., Farrokhi, S. and Nabipour, I. (2020) COVID-19 cytokine storm: The anger of inflammation. $C y$ - 
tokine 133, 155151

Mak, E. (2020) Chinese biotech's apply new tech to accelerate drug R\&D for COVID-19. Available at: https://www.bioworld.com/article s/433289-chinese-biotechs-apply-new-tech-to-accelerate-dru g-rd-for-covid-19 (Accessed: February 25, 2020)

Mani, J. S., Johnson, J. B., Steel, J. C., Broszczak, D. A., Neilsen, P. M., Walsh, K. B. and Naiker, M. (2020) Natural product-derived phytochemicals as potential agents against coronaviruses: A review. Virus Research 284, 197989.

Maurya, V. K., Kumar, S., Prasad, A. K., Bhatt, M. L. B. and Saxena, S. K. (2020) Structure-based drug designing for potential antiviral activity of selected natural products from Ayurveda against SARS-CoV-2 spike glycoprotein and its cellular receptor. Virusdisease 31, 179-193.

McCullough, P. A., Kelly, R. J., Ruocco, G., Lerma, E., Tumlin, J., Wheelan, K. R., Katz, N., Lepor, N. E., Vijay, K., Carter, H., Singh, B., McCullough, S. P., Bhambi, B. K., Palazzuoli, A., De Ferrari, G. M., Milligan, G. P., Safder, T., Tecson, K. M., Wang, D. D., McKinnon, J. E., O'Neill, W. W., Zervos, M. and Risch, H. A. (2020) Pathophysiological Basis and Rationale for Early Outpatient Treatment of SARS-CoV-2 (COVID-19) Infection. The American Journal of Medicine (in press).

Mehta, P., McAuley, D. F., Brown, M., Sanchez, E., Tattersall, R. S. and Manson, J. J. (2020) COVID-19: consider cytokine storm syndromes and immunosuppression. The Lancet 395, 1033-1034.

Mehta, P. K. and Griendling, K. K. (2007) Angiotensin II cell signaling: physiological and pathological effects in the cardiovascular system. American Journal of Physiology-Cell Physiology 292, C82-C97.

Mevada, V., Dudhagara, P., Gandhi, H., Vaghamshi, N., Beladiya, U., Patel, R. (2020) Drug repurposing of approved drugs Elbasvir, Ledipasvir, Paritaprevir, Velpatasvir, Antrafenine and Ergotamine for combating COVID19. ChemRxiv. (in press).

Messerli, F. H., Siontis, G. C. M. and Rexhaj, E. (2020) COVID-19 and renin angiotensin blockers. Circulation 141, 2042-2044.

Mohammed El Tabaa, Manar. and Mohammed El Tabaa, Maram (2020) Targeting Neprilysin (Nep) Pathways: A Potential New Hope to Defeat Covid-19 Ghost. Biochem Pharmacol 178, 114057.

Nahrstedt, A., Kant, J. and Wray, V. (1982) Acalyphin, a cyanogenic glucoside from Acalypha indica. Phytochemistry 21, 101-105.

Narkhede, R. R., Pise, A. V., Cheke, R. S. and Shinde, S. D. (2020) Recognition of natural products as potential inhibitors of COVID-19 main protease (Mpro): In-Silico evidences. Natural Products and Bioprospecting (in press).

Nicoletti, F., Fagone, P., Meroni, P., McCubrey, J. and Bendtzen, K. (2011) Mtor as a multifunctional therapeutic target in HIV infection. Drug Discovery Today 16, 715-721.

Nathan, C. (2020) Neutrophils and COVID-19:nots, nets, and knots. Journal of Experimental Medicine 217, e20201439.

Nguyen, T. T. H., Woo, H., Kang, H., Nguyen, V. D., Kim, Y., Kim, D., Ahn, S., Xia, Y. and Kim, D. (2012) Flavonoid-mediated inhibition of SARS coronavirus 3C-like protease expressed in Pichia pastoris. Biotechnology Letters 34, 831-838.

Oostra, M., de Haan, C. A. M. and Rottier, P. J. M. (2007) The 29nucleotide deletion present in human but not in animal severe acute respiratory syndrome coronaviruses disrupts the functional expression of open reading frame 8. Journal of Virology 81, 13876-13888.

Pai, W., Lo, W., Hsu, T., Peng, C. and Wang, H. (2017) Angiotensin-(17) inhibits thrombin-induced endothelial phenotypic changes and reactive oxygen species production via NADPH oxidase 5 downregulation. Frontiers in Physiology 8, 994.

Paintsil, E. and Cheng, Y. (2009) Antiviral agents. Encyclopedia of Microbiology 223-257.

Pal, A., Pawar, A., Goswami, K., Sharma, P. and Prasad, R. (2020) Hydroxychloroquine and Covid-19: A cellular and molecular biology based update. Indian Journal of Clinical Biochemistry 35, 274-284.

Patel, V. B., Zhong, J., Grant, M. B. and Oudit, G. Y. (2016) Role of the ACE2/Angiotensin 1-7 axis of the renin-angiotensin system in heart failure. Circulation Research 118, 1313-1326.

Patil, T. R. and Limaye, R. P. (2017) Effect of Euphorbia prostrata on the wound healing in excisional wound model in rats. International Journal of Pharmacognosy and Phytochemical Research 9, 10.25258/phyto.v9i09.10310.
Patwardhan, B., Gautam, P. C., Gautam, M., Tillu, G., Chopra, A., Gairola, S. and Jadhav, S. (2020) Ayurveda Rasayana in prophylaxis of COVID19. Current Science 118,1158-1160.

Petralia, M. C., Mazzon, E., Fagone, P., Basile, M. S., Lenzo, V., Quattropani, M. C., Di Nuovo, S., Bendtzen, K. and Nicoletti, F. (2020) The cytokine network in the pathogenesis of major depressive disorder. Close to translation?. Autoimmunity Reviews 19, 102504.

Pirola, C. J. and Sookoian, S. (2020) Estimation of renin-angiotensinaldosterone-system (RAAS)-inhibitor effect on the COVID-19 outcome: A meta-analysis. Journal of Infection 81, 276-281.

Pizzorno, A., Padey, B., Dubois, J., Julien, T., Traversier, A., Dulière, V., Brun, P., Lina, B., Rosa-Calatrava, M. and Terrier, O. (2020) In vitro evaluation of antiviral activity of single and combined repurposable drugs against SARS-CoV-2. Antiviral Research 181, 104878.

Rahman, N., Basharat, Z., Yousuf, M., Castaldo, G., Rastrelli, L. and Khan, H. (2020) Virtual screening of natural products against type II transmembrane serine protease (TMPRSS2), the priming agent of coronavirus 2 (SARS-CoV-2). Molecules 25, 2271.

Ramaiah, M. J. (2020) Mtor inhibition and P53 Activation, Micrornas: The possible therapy against pandemic COVID-19. Gene Reports 20, 100765.

Rane, J.S., Chatterjee, A., Kumar, K. and Ray, S. (2020) Targeting SARSCoV-2 spike protein of COVID-19 with naturally occurring phytochemicals: An in silico study for drug development. Chemrxiv (in press)

Reichert, J. M. (2003) Trends in development and approval times for new therapeutics in the United States. Nature Reviews Drug Discovery 2 , 695-702.

Richardson, P., Griffin, I., Tucker, C., Smith, D., Oechsle, O., Phelan, A., Rawling, M., Savory, E. and Stebbing, J. (2020a) Baricitinib as potential treatment for 2019-nCoV acute respiratory disease. The Lancet $\mathbf{3 9 5}$, e30-e31.

Richardson, S., Hirsch, J. S., Narasimhan, M., Crawford, J. M., McGinn, T., Davidson, K. W., and the Northwell, C.-R. C., Barnaby, D. P., Becker, L. B., Chelico, J. D., Cohen, S. L., Cookingham, J., Coppa, K., Diefenbach, M. A., Dominello, A. J., Duer-Hefele, J., Falzon, L., Gitlin, J., Hajizadeh, N., Harvin, T. G., Hirschwerk, D. A., Kim, E. J., Kozel, Z. M., Marrast, L. M., Mogavero, J. N., Osorio, G. A., Qiu, M. and Zanos, T. P. (2020b) Presenting characteristics, comorbidities, and outcomes among 5700 patients hospitalized with COVID-19 in the New York city area. JAMA 323, 2052.

Roche, J. A. and Roche, R. (2020) A hypothesized role for dysregulated bradykinin signaling in COVID-19 respiratory complications. The FASEB Journal 34, 7265-7269.

Romagnoli, S., Peris, A., De Gaudio, A. R. and Geppetti, P. (2020) SARSCoV-2 and COVID-19: From the bench to the bedside. Physiological Reviews 100, 1455-1466.

Rosendaal, F. R. (2020) Review of: "Hydroxychloroquine and azithromycin as a treatment of COVID-19: results of an openlabel non-randomized clinical trial Gautret et al 2010International Journal of Antimicrobial Agents 56, 106063.

Rowley, A. H. (2020) Understanding SARS-CoV-2-related multisystem inflammatory syndrome in children. Nature Reviews Immunology 20, 453-454.

Ruiz-Ortega, M., Lorenzo, O., Suzuki, Y., Rupérez, M. and Egido, J. (2001) Proinflammatory actions of angiotensins. Current Opinion in Nephrology and Hypertension 10, 321-329.

Rushworth, C. A., Guy, J. L. and Turner, A. J. (2008) Residues affecting the chloride regulation and substrate selectivity of the angiotensinconverting enzymes (ACE and ACE2) identified by site-directed mutagenesis. FEBS Journal 275, 6033-6042.

Ryu, Y. B., Jeong, H. J., Kim, J. H., Kim, Y. M., Park, J., Kim, D., Naguyen, T. T. H., Park, S., Chang, J. S. and Park, K. H. (2010) Biflavonoids from Torreya nucifera displaying SARS-CoV 3CLpro inhibition. Bioorganic \& Medicinal Chemistry 18, 7940-7947.

Sallenave, J. and Guillot, L. (2020) Innate immune signaling and proteolytic pathways in the resolution or exacerbation of SARS-CoV-2 in Covid-19: key therapeutic targets? Frontiers in Immunology 11

Samuel, C. E. (2001) Antiviral actions of interferons. Clinical Microbiology Reviews 14, 778-809.

Sanders, J. M., Monogue, M. L., Jodlowski, T. Z. and Cutrell, J. B. (2020) 
Pharmacologic Treatments for coronavirus disease 2019 (COVID-19). JAMA 328, 1824-1836.

Sano, M., Fukuda, K., Kodama, H., Pan, J., Saito, M., Matsuzaki, J., Takahashi, T., Makino, S., Kato, T. and Ogawa, S. (2000) Interleukin-6 family of cytokines mediate angiotensin II-induced cardiac hypertrophy in rodent cardiomyocytes. Journal of Biological Chemistry 275, $29717-$ 29723.

Santos, R. A. S., Sampaio, W. O., Alzamora, A. C., Motta-Santos, D., Alenina, N., Bader, M. and Campagnole-Santos, M. J. (2018) The ACE2/Angiotensin-(1-7)/MAS axis of the renin-angiotensin system: focus on angiotensin-(1-7). Physiological Reviews 98, 505-553.

Santos, J., Brierley, S., Gandhi, M. J., Cohen, M. A., Moschella, P. C. and Declan, A. B. L. (2020) Repurposing therapeutics for potential treatment of SARS-CoV-2: A review. Viruses 12, 705.

Schrader, T., Dudek, S. E., Schreiber, A., Ehrhardt, C., Planz, O. and Ludwig, S. (2018) The clinically approved MEK inhibitor Trametinib efficiently blocks influenza a virus propagation and cytokine expression. Antiviral Research 157, 80-92.

Schwarz, S., Sauter, D., Wang, K., Zhang, R., Sun, B., Karioti, A., Bilia, A., Efferth, T. and Schwarz, W. (2014) Kaempferol Derivatives as Antiviral Drugs against the 3 a Channel Protein of Coronavirus. Planta Medica 80, 177-182.

Siddiqi, H. K. and Mehra, M. R. (2020) COVID-19 illness in native and immunosuppressed states: A clinical-therapeutic staging proposal. The Journal of Heart and Lung Transplantation 39, 405-407.

Silhol, F., Sarlon, G., Deharo, J. and Vaïsse, B. (2020) Downregulation of ACE2 induces overstimulation of the renin-angiotensin system in COVID-19: should we block the renin-angiotensin system? Hypertension Research 43, 854-856.

da Silva, J. K. R., Figueiredo, P. L. B., Byler, K. G. and Setzer, W. N. (2020) Essential oils as antiviral agents, potential of essential oils to treat SARS-CoV-2 infection: An in-silico investigation. International Journal of Molecular Sciences 21, 3426.

Skurk, T., van Harmelen, V. and Hauner, H. (2004) Angiotensin II stimulates the release of interleukin- 6 and interleukin- 8 from cultured human adipocytes by activation of NF-kappaB. Arteriosclerosis, Thrombosis, and Vascular Biology 24, 1199-1203.

Song, H. D., Tu, C. C., Zhang, G. W., Wang, S. Y., Zheng, K., Lei, L. C., Chen, Q. X., Gao, Y. W., Zhou, H. Q., Xiang, H., Zheng, H. J., Chern, S. W., Cheng, F., Pan, C. M., Xuan, H., Chen, S. J., Luo, H. M., Zhou, D. H., Liu, Y. F., He, J. F., Qin, P. Z., Li, L. H., Ren, Y. Q., Liang, W. J., Yu, Y. D., Anderson, L., Wang, M., Xu, R. H., Wu, X. W., Zheng, H. Y., Chen, J. D., Liang, G., Gao, Y., Liao, M., Fang, L., Jiang, L. Y., Li, H., Chen, F., Di, B., He, L. J., Lin, J. Y., Tong, S., Kong, X., Du, L., Hao, P., Tang, H., Bernini, A., Yu, X. J., Spiga, O., Guo, Z. M., Pan, H. Y., He, W. Z., Manuguerra, J. C., Fontanet, A., Danchin, A., Niccolai, N., Li, Y. X., Wu, C. I. and Zhao, G. P. (2005) Cross-host evolution of severe acute respiratory syndrome coronavirus in palm civet and human. Proceedings of the National Academy of Sciences 102, 2430-2435.

Soy, M., Keser, G., Atagündüz, P., Tabak, F., Atagündüz, I. and Kayhan, S. (2020) Cytokine storm in COVID-19: pathogenesis and overview of anti-inflammatory agents used in treatment. Clinical Rheumatology 39, 2085-2094.

Stebbing, J., Krishnan, V., de Bono, S., Ottaviani, S., Casalini, G., Richardson, P. J., Monteil, V., Lauschke, V. M., Mirazimi, A., Youhanna, S., Tan, Y. J., Baldanti, F., Sarasini, A., Terres, J. A. R., Nickoloff, B. J., Higgs, R. E., Rocha, G., Byers, N. L., Schlichting, D. E., Nirula, A., Cardoso, A., Corbellino, M. and Sacco Baricitinib Study, G. (2020) Mechanism of Baricitinib supports artificial intelligence-predicted testing in COVID-19 patients. EMBO Molecular Medicine 12, e12697.

Tai, B. H., Nhiem, N. X., Van Doan, V., Yen, P. H., Quang, T. H., Trang, D. T., Yen, D. T. H., Cuc, N. T. and Van Kiem, P. (2018) Isolation of spirostanol glycosides from Solanum nigrum. Vietnam Journal of Chemistry 56, 548-552.

Tay, M. Z., Poh, C. M., Rénia, L., MacAry, P. A. and Ng, L. F. P. (2020) The trinity of COVID-19: immunity, inflammation and intervention. Nature Reviews Immunology 20, 363-374.

Tan, E. L. C., Ooi, E. E., Lin, C., Tan, H. C., Ling, A. E., Lim, B. and Stanton, L. W. (2004) Inhibition of SARS coronavirus infection in vitro with clinically approved antiviral drugs. Emerging Infectious Diseases
10, 581-586

Tang, N., Li, D., Wang, X. and Sun, Z. (2020) Abnormal coagulation parameters are associated with poor prognosis in patients with novel coronavirus pneumonia. Journal of Thrombosis and Haemostasis 18, 844847 .

Tchesnokov, E., Feng, J., Porter, D. and Götte, M. (2019) Mechanism of inhibition of Ebola virus RNA-dependent RNA polymerase by remdesivir. Viruses 11, 326.

Troiani, T., Vecchione, L., Martinelli, E., Capasso, A., Costantino, S., Ciuffreda, L. P., Morgillo, F., Vitagliano, D., D'Aiuto, E., De Palma, R., Tejpar, S., Van Cutsem, E., De Lorenzi, M., Caraglia, M., Berrino, L. and Ciardiello, F. (2012) Intrinsic resistance to selumetinib, a selective inhibitor of MEK1/2, by cAMP-dependent protein kinase A activation in human lung and colorectal cancer cells. British Journal of Cancer 106, 1648-1659.

Uhal, B. D., Li, X., Xue, A., Gao, X. and Abdul-Hafez, A. (2011) Regulation of alveolar epithelial cell survival by the ACE-2/angiotensin 17/Mas axis. American Journal of Physiology-Lung Cellular and Molecular Physiology 301, L269-L274.

U1 Qamar, M. T., Alqahtani, S. M., Alamri, M. A. and Chen, L. L. (2020) Structural basis of SARS-CoV-2 3CL(pro) and anti-COVID-19 drug discovery from medicinal plants. Journal of Pharmaceutical Analysis 10, 313-319.

Vabret, N., Britton, G. J., Gruber, C., Hegde, S., Kim, J., Kuksin, M., Levantovsky, R., Malle, L., Moreira, A., Park, M. D., Pia, L., Risson, E., Saffern, M., Salome, B., Esai Selvan, M., Spindler, M. P., Tan, J., van der Heide, V., Gregory, J. K., Alexandropoulos, K., Bhardwaj, N., Brown, B. D., Greenbaum, B., Gumus, Z. H., Homann, D., Horowitz, A., Kamphorst, A. O., Curotto de Lafaille, M. A., Mehandru, S., Merad, M., Samstein, R. M. and Sinai Immunology Review Project (2020) Immunology of COVID-19: Current state of the science. Immunity 52, 910-941.

Van Laecke, S. and Van Biesen, W. (2017) Severe hypertension with renal thrombotic microangiopathy: what happened to the usual suspect? Kidney International 91, 1271-1274.

Viana, S. D., Nunes, S. and Reis, F. (2020) ACE2 imbalance as a key player for the poor outcomes in COVID-19 patients with age-related comorbidities - Role of gut microbiota dysbiosis. Ageing Research Reviews 62, 101123.

Verdecchia, P., Cavallini, C., Spanevello, A. and Angeli, F. (2020) COVID19: ACE2centric infective disease? Hypertension 76, 294-299.

Wang, Y., Zhang, D., Du, G., Du, R., Zhao, J., Jin, Y., Fu, S., Gao, L., Cheng, Z., Lu, Q., Hu, Y., Luo, G., Wang, K., Lu, Y., Li, H., Wang, S., Ruan, S., Yang, C., Mei, C., Wang, Y., Ding, D., Wu, F., Tang, X., Ye, X., Ye, Y., Liu, B., Yang, J., Yin, W., Wang, A., Fan, G., Zhou, F., Liu, Z., Gu, X., Xu, J., Shang, L., Zhang, Y., Cao, L., Guo, T., Wan, Y., Qin, H., Jiang, Y., Jaki, T., Hayden, F. G., Horby, P. W., Cao, B. and Wang, C. (2020) Remdesivir in adults with severe COVID-19: a randomised, double-blind, placebo-controlled, multicentre trial. The Lancet 395, 1569-1578.

Wiersinga, W. J., Rhodes, A., Cheng, A. C., Peacock, S. J., Prescott, H. C. (2020) Pathophysiology, transmission, diagnosis, and treatment of coronavirus disease 2019 (COVID-19). JAMA 324, 782.

World Health Organization. (2020) Coronavirus disease (COVID-19) pandemic. Availableat:https://www.who.int/emergencies/dise ases/novel-coronavirus-2019 (Accessed: September 27, 2020).

Wu, C., Liu, Y., Yang, Y., Zhang, P., Zhong, W., Wang, Y., Wang, Q., Xu, Y., Li, M., Li, X., Zheng, M., Chen, L. and Li, H. (2020) Analysis of therapeutic targets for SARS-CoV-2 and discovery of potential drugs by computational methods. Acta Pharmaceutica Sinica B 10, 766-788.

Yang, J. K., Feng, Y., Yuan, M. Y., Yuan, S. Y., Fu, H. J., Wu, B. Y., Sun, G. Z., Yang, G. R., Zhang, X. L., Wang, L., Xu, X., Xu, X. P. and Chan, J. C. N. (2006) Plasma glucose levels and diabetes are independent predictors for mortality and morbidity in patients with SARS. Diabetic Medicine 23, 623-628.

Yao, X., Ye, F., Zhang, M., Cui, C., Huang, B., Niu, P., Liu, X., Zhao, L., Dong, E., Song, C., Zhan, S., Lu, R., Li, H., Tan, W. and Liu, D. (2020) In vitro antiviral activity and projection of optimized dosing design of hydroxychloroquine for the treatment of severe acute respiratory syndrome coronavirus 2 (SARS-CoV-2). Clinical Infectious Diseases 71, 
732-739.

Ye, Q., Wang, B. and Mao, J. (2020) The pathogenesis and treatment of the 'Cytokine Storm' in COVID-19. Journal of Infection 80, 607-613.

Y. Yuen, C. K., Lam, J. Y., Wong, W. M., Mak, L. F., Wang, X., Chu, H., Cai, J. P., Jin, D. Y., To, K. K., Chan, J. F., Yuen, K. Y. and Kok, K. H. (2020) SARS-CoV-2 nsp13, nsp14, nsp15 and orf6 function as potent interferon antagonists. Emerging Microbes and Infections 9, 1418-1428.

Zhang, X. W. and Yap, Y. L. (2004) Old drugs as lead compounds for a new disease? Binding analysis of SARS coronavirus main proteinase with $\mathrm{HIV}$, psychotic and parasite drugs. Bioorganic and Medicinal Chemistry 12, 2517-2521.

Zhang, Y., Zheng, N., Hao, P., Cao, Y. and Zhong, Y. (2005) A molecular docking model of SARS-CoV S1 protein in complex with its receptor, human ACE2. Computational Biology and Chemistry 29, 254-257.

Zhang, L. and Zhou, R. (2020) Structural basis of the potential binding mechanism of remdesivir to SARS-CoV-2 RNA-dependent RNA polymerase. Journal of Physical Chemistry B 124, 6955-6962.

Zhang, X., Zhang, Y., Qiao, W., Zhang, J. and Qi, Z. (2020) Baricitinib, a drug with potential effect to prevent SARS-COV-2 from entering target cells and control cytokine storm induced by COVID-19. International Immunopharmacology 86, 106749.
Zheng, Y., Li, R. and Liu, S. (2020) Immunoregulation with mTOR inhibitors to prevent covid-19 severity: a novel intervention strategy beyond vaccines and specific antiviral medicines. Journal of Medical Virology 92, 1495-1500.

Zhang, Y., Zhang, J., Chen, Y., Luo, B., Yuan, Y., Huang, F., Yang, T., Yu, F., Liu, J., Liu, B., Song, Z., Chen, J., Pan, T., Xu Zhang, X., Li, Y., Li, R., Huang. W., Xiao, F., and Zhang, H. (2020) The ORF8 Protein of SARS-CoV-2 mediates immune evasion through potently downregulating MHC-I bioRxiv (in press).

Zhong, N., Zheng, B., Li, Y., Poon, L., Xie, Z., Chan, K., Li, P., Tan, S., Chang, Q., Xie, J., Liu, X., Xu, J., Li, D., Yuen, K., Peiris, J. and Guan, Y. (2003) Epidemiology and cause of severe acute respiratory syndrome (SARS) in Guangdong, People's Republic of China, in February, 2003. The Lancet 362, 1353-1358.

Zhou, X., He, X., Wang, G., Gao, H., Zhou, G., Ye, W. and Yao, X. (2006) Steroidal saponins from Solanum nigrum. Journal of Natural Products 69, 1158-1163.

Zou, Y., Guo, H., Zhang, Y., Zhang, Z., Liu, Y., Wang, J., Lu, H. and Qian, Z. (2020) Analysis of coagulation parameters in patients with COVID19 in Shanghai, China. Bioscience Trends 14, 285-289. 